\title{
Transcriptome analysis reveals the mechanism by which the biocontrol fungus Chaetomium globosum CEF-082 controls Verticillium wilt in cotton
}

Yun Zhang ( $\nabla$ yunzhangxgf@126.com )

Nanjing Agricultural University https://orcid.org/0000-0002-9448-6202

Na Yang

Nanjing Agricultural University

Lihong Zhao

Chinese Academy of Agricultural Sciences Cotton Research Institute

Heqin Zhu

Chinese Academy of Agricultural Sciences Cotton Research Institute

Canming Tang

Nanjing Agricultural University

Research article

Keywords: Transcriptome, Verticillium wilt, Mechanism, Biocontrol fungi

Posted Date: October 11th, 2019

DOI: https://doi.org/10.21203/rs.2.15513/v1

License: (a) This work is licensed under a Creative Commons Attribution 4.0 International License.

Read Full License 


\section{Abstract}

Background: Verticillium wilt of cotton is a serious soil-borne disease that causes a substantial reduction in cotton yield. A previous study showed that the endophytic fungus Chaetomium globosum CEF-082 could control Verticillium wilt of cotton, but the molecular mechanism by which CEF-082 controls Verticillium wilt is still unknown.

Results: To study the mechanism by which CEF-082 controls Verticillium wilt, the transcriptome of cotton seedlings pretreated with CEF-082 was sequenced. The results revealed 5638 DEGs $24 \mathrm{~h}$ post-inoculation with CEF-082, and 2921 and 2153 DEGs 12 and 48 h post-inoculation with Verticillium dahliae, respectively. At twenty-four hours post-inoculation with CEF-082, KEGG enrichment analysis indicated that the DEGs were mainly enriched in plant-pathogen interaction, MAPK signalling pathway-plant, flavonoid biosynthesis, and phenylpropanoid biosynthesis. There were 1209 DEGs specifically induced after inoculation with CEF-082 and V. dahliae . GO enrichment indicated that these DEGs were mainly enriched in the terms reactive oxygen species metabolic process, hydrogen peroxide metabolic process, defence response, superoxide dismutase activity, and antioxidant activity. Here, many genes, such as ERF, CNGC, FLS2, MYB, GST and CML, were identified that regulate crucial points in defence-related pathways and that may contribute to $\mathrm{V}$. dahliae resistance in cotton. These results provide a basis for the understanding of the molecular mechanism by which biocontrol fungi control Verticillium wilt.

Conclusions: In this study, we found that CEF-082 could regulate multiple metabolic pathways in cotton. After treatment with Verticillium dahliae, the defence response of cotton plants pre-inoculated with CEF082 was strengthened.

\section{Background}

Cotton (Gossypium spp.) is an important economic crop that is cultivated worldwide. Verticillium wilt of cotton is a serious vascular disease that detrimentally affects cotton yield and fibre quality [1]. Verticillium wilt is caused by the soil-borne fungus Verticillium dahliae Kleb. This disease can cause cotton yellowing, wilt, defoliation, and ultimately death [2]. It is difficult to control this pathogen due to its long-term survival as microsclerotia in the soil and its broad host range [3]. To date, no fungicide has been identified that can cure Verticillium wilt of upland cotton (Gossypium hirsutum L.) after plants have been infected $[2,4-5]$.

Many biocontrol bacteria and fungi have been studied to assess their ability to control Verticillium wilt and other plant diseases, and substantial progress has been made. Iturins mediate the defence response, and significantly activate $P R 1, \angle O X$, and $P R 10$ at $24 \mathrm{~h}$ after $V$. dahliae infection [6]. The nonvolatile substances produced by CEF-818 (Penicillium simplicissimum), CEF-325 (Fusarium solani), CEF-714 (Leptosphaeria sp.), and CEF-642 (Talaromyces flavus) inhibit $V$. dahliae growth [7]. The application of the nonpathogenic isolate Fusarium oxysporum 47 (Fo47) reduced the symptoms of Verticillium wilt in pepper, and three defence genes, CABPR1, CACHI2 and CASC1, were upregulated in the roots treated with 
Fo47 [8]. K-165 induced the resistance of Arabidopsis thaliana to Verticillium wilt [9]. Bacillus subtilis DZSY21 reduced the disease severity of southern corn leaf blight and upregulated the expression levelof PDF1.2 in DZSY21-treated plants [10]. The preinoculation of cauliflower with Verticillium Vt305 reduced symptom development and the colonization of plant tissues by $V$. longisporum [11]. However, the mechanism of the biological control of plant diseases remains unclear.

It has been reported that cotton plants infected with $V$. dahliae induce a series of immune reactions. In recent years, transcriptomic studies of the defence responses of plants infected with $V$. dahliae have becoming increasing common, and several signal transduction pathways and key genes have been identified, including plant hormone signal transduction, plant-pathogen interaction, and phenylpropanoidrelated and ubiquitin-mediated signals in cotton; additionally, these studies have investigated the key regulatory gene families, such as receptor-like protein kinases (RLKs), WRKY transcription factors and cytochrome P450s (CYPs) [3]. PAL, 4CL, CAD, CCOAOMT, and COMT in the phenylalanine metabolism pathway have been shown to be upregulated in sea-island cotton [2]; 401 transcription factors, mainly in the MYB, bHLH, AP2-EREBP, NAC, and WRKY families, have been shown to be up- or downregulated by $V$. dahliae in A. thaliana [12]; and CNGC, RBOH, FLS2, JAZ, MYC2, NPR1 and TGA have been shown to be induced by $V$. dahliae in sunflower [13]. However, there are few studies on the transcriptome level in plants induced by biocontrol fungi or induced by biocontrol fungi and $V$. dahliae at the same time.

In previous studies, we found that the endophytic fungus CEF-082 isolated from upland cotton plants could control Verticillium wilt in cotton. However, the molecular mechanism of biocontrol is unknown. Therefore, the purpose of this study is to reveal the molecular mechanism by which CEF-082 controls Verticillium wilt in cotton via RNA sequence analysis to provide a basis for the understanding of the biological control of plant diseases.

\section{Methods}

\section{Fungal strain culture}

Endophytic Chaetomium globosum CEF-082 of cotton was cultured on potato dextrose agar (PDA) plates for $20 \mathrm{~d}$. Spores were washed with sterile water and diluted to a $1 \times 10^{5} \mathrm{CFU} / \mathrm{mL}$ spore suspension. V. dahliae VD1070-2 was cultured on PDA for 7 d, inoculated into liquid Czapek-Dox medium [14], and cultured in the dark at $25^{\circ} \mathrm{C}$ and $150 \mathrm{rpm}$ for $7 \mathrm{~d}$. The mycelia were filtered out and diluted to a $1 \times 10^{7}$ $\mathrm{CFU} / \mathrm{mL}$ spore suspension.

\section{Cotton inoculation treatment}

Jimian 11, a highly Verticillium wilt-susceptible upland cotton variety, was provided by Professor Heqin Zhu from State Key Laboratory of Cotton Biology, Institute of Cotton Research of Chinese Academy of Agricultural Sciences. It is a hybrid [(Jihan $4 \times \mathrm{Ke} 4104) \mathrm{F} \_2 \times 74$ Yu102]. The seeds were sterilized with $70 \%$ alcohol for 1 minute and with $1.05 \%$ sodium hypochlorite for 10 minutes and then washed with 
sterile water 5 times. The cotton seeds were planted in vermiculite and transferred to a plastic pot (25 $\mathrm{cm} \times 15 \mathrm{~cm}$ ) containing $2000 \mathrm{~mL}$ of culture solution after emergence. The culture solution was prepared according to the methods of Zhang et al. [15], with some modifications. In this study, $2 \mathrm{mM} \mathrm{NaCl}$ was used instead of $2.5 \mathrm{mM} \mathrm{KCl}$, while the other 9 mineral nutrients were the same. Twenty plants were cultured per pot. The cotton plants were inoculated with the CEF-082 spore suspension by soaking the cotton roots in the spore suspension for 40 minutes prior to the first true leaf flattening, and water, instead of the CEF-082 spore suspension, was used as the control group. Zero, 6 and $24 \mathrm{~h}$ later, leaf samples were taken, and $24 \mathrm{~h}$ was considered $0 \mathrm{~h}$ before inoculated with $V$. dahliae. After that, the same method was used to inoculate $V$. dahliae VD1070-2 into the treatment group and the control group. Then, leaf samples were collected at $12 \mathrm{~h}, 1 \mathrm{~d}, 2 \mathrm{~d}, 3 \mathrm{~d}, 5 \mathrm{~d}$ and $7 \mathrm{~d}$.

\section{Determination of the hydrogen peroxide $\left(\mathrm{H}_{2} \mathrm{O}_{2}\right)$ content}

$\mathrm{H}_{2} \mathrm{O}_{2}$ content was estimated according to Anket Sharma et al. [16] with minor modifications. Approximately $0.1 \mathrm{~g}$ of cotton leaves was weighed and added to $1 \mathrm{~mL}$ of acetone for ice bath homogenization. Then, the samples were centrifuged at $8000 \mathrm{~g}$ and $4^{\circ} \mathrm{C}$ for 10 minutes, and the supernatant was collected. Then, $25 \mu \mathrm{L}$ of $20 \%$ titanium chloride in concentrated $\mathrm{HCl}$ and $200 \mu \mathrm{L}$ of ammonia solution (17 M) were added. The precipitate was then washed 3 times with acetone. The washed precipitates were dissolved in $1.5 \mathrm{~mL}$ of $\mathrm{H}_{2} \mathrm{SO}_{4}(2 \mathrm{~N})$, and the absorbance was read at $415 \mathrm{~nm}$.

\section{Control effect of biocontrol fungus CEF-082 on Verticillium wilt of cotton}

The above hydroponic seedlings were investigated at $14 \mathrm{~d}$ post-inoculation (dpi) with VD1070-2. The method of investigation was consistent with that of Zhu et al. [17].

\section{RNA-seq}

A polysaccharide polyphenol RNA extraction kit (TianGen) was used to extract RNA from cotton leaves. Electrophoresis was performed, and Drop one was used to detect the concentration and quality of RNA. Transcriptome sequencing was performed for the $24 \mathrm{~h}(0 \mathrm{~h}$ (TOh, COh)), $12 \mathrm{~h}(\mathrm{~T} 12 \mathrm{~h}, \mathrm{C} 12 \mathrm{~h})$ and $48 \mathrm{~h}$ ( $\mathrm{T} 48 \mathrm{~h}, \mathrm{C} 48 \mathrm{~h}$ ) samples. Three replicates were performed, and there were 18 samples. The construction of the DNA library and sequencing were performed by BGI company. The raw reads obtained from sequencing were filtered to obtain clean reads, which were spliced and compared to the reference genome.

\section{Screening and analysis of differentially expressed genes (DEGs)}


To improve the accuracy of the identification of DEGs, we defined DEGs with a fold change $>=2$ and Qvalue $<0.001$ as significant. Kyoto Encylopedia of Genes and Genomes (KEGG) and Gene Ontology (GO) analyses of these genes were carried out.

\section{Principal component analysis (PCA)}

The princomp function in R software was used for PCA analysis, and the ggplot2 package in R software was used to draw figures.

\section{Quantitative reverse-transcription-PCR (qRT-PCR) analysis}

Some genes were selected for RT-PCR to calculate whether the trend of gene expression was consistent with the transcriptome sequencing results. RNA was extracted from sample leaves and re-transcribed into cDNA. Primers were obtained from the upland cotton gene fluorescence quantitative specific primer database (https://biodb.swu.edu.cn/qprimerdb/) (Table S1), and gene expression was calculated by $2^{-}$ $\Delta \mathrm{Ct}$

\section{Results}

\section{Control effect of CEF-082 on Verticillium wilt of cotton and the $\mathrm{H}_{2} \mathrm{O}_{2}$ content}

The disease index was 18.61 in the control group (water+ $V$. dahliae) and 7.62 in the treatment group (CEF-082+ V. dahliae) $14 \mathrm{~d}$ after $V$. dahliae inoculation (Fig. 1A). The results showed that CEF-082 could control Verticillium wilt of cotton, and the control effect was 59.1\% (Fig. 1C).

The $\mathrm{H}_{2} \mathrm{O}_{2}$ content in the treatment group was higher than that in the control group throughout the majority of the duration of the experiment and lower than that in the control group at 5 dpi with $\mathrm{V}$. dahliae. The $\mathrm{H}_{2} \mathrm{O}_{2}$ content in the treatment group was highest at $2 \mathrm{dpi}(12.80 \mu \mathrm{mol} / \mathrm{g})$, while the $\mathrm{H}_{2} \mathrm{O}_{2}$ content in the control group was highest at $1 \mathrm{dpi}(10.38 \mu \mathrm{mol} / \mathrm{g})$. The changes in the two groups were similar and were stable 5 d later (Fig. 1B).

\section{PCA}

The minimum correlation between the three replicates was $95.5 \%$ (Fig. S1). According to the results of the PCA, at $0 \mathrm{~h}$ and $12 \mathrm{~h}$, the gene expression difference between the control group and the treatment group was relatively small, but there was a big difference at $48 \mathrm{~h}$ (Fig. 2). These results revealed a gene expression difference between the CEF-082-treated group and the non-CEF-082-treated group. 


\section{qRT-PCR}

RNA was extracted from cotton transcriptome samples and reverse transcribed into cDNA. Twelve DEGs were selected. The gene expression levels in the control and treatment groups were compared by qRTPCR. The results showed that nine of the 12 genes were upregulated, which was consistent with the results of their upregulated expression in the transcriptome, while three genes were downregulated, which was inconsistent with the expression of the transcriptome genes, namely, Gh_D12G2793, Gh_D08G2484 and Gh_D05G3615 (Fig. 3). In addition, the level of upregulation of 5 genes in the qRT-PCR data was lower than that in the RNA-seq data. The qRT-PCR data were consistent with the transcriptome data up to $75 \%$.

\section{Functional annotation and enrichment analysis of the DEGs}

The average clean reads of the 18 samples was 62.08. The lowest Q20 value of the clean reads was 97.93 , and the lowest Q30 value was 90.06 (Table S2). A total of 47183 new transcripts were found, of which 7288 belonged to new protein-coding genes (Table S3).

There were 3480 upregulated and 2158 downregulated DEGs at 0 h, 1716 upregulated and 1205 downregulated DEGs at $12 \mathrm{~h}$, and 1524 upregulated and 629 downregulated DEGs at $48 \mathrm{~h}$ (Fig. 4). The highest number of DEGs were identified after inoculation with CEF-082 for $24 \mathrm{~h}$. After inoculation with $V$. dahliae, the number of DEGs gradually decreased.

\section{Effect of CEF-082 treatment on cotton seedlings}

After inoculation with CEF-082 for $24 \mathrm{~h}(0 \mathrm{~h}), 5638 \mathrm{DEG}$ were identified, and KEGG pathway enrichment analysis revealed 15 significantly enriched pathways, including plant-pathogen interaction, MAPK signalling pathway-plant, flavonoid biosynthesis, phenylpropanoid biosynthesis, galactose metabolism, arachidonic acid metabolism, carotenoid biosynthesis, glutathione metabolism, sesquiterpenoid and triterpenoid biosynthesis, linoleic acid metabolism, other glycan degradation, glycosphingolipid biosynthesis - ganglio series, brassinosteroid biosynthesis, diterpenoid biosynthesis and sphingolipid metabolism (Q-value <0.05) (Table 1). In the plant-pathogen interaction pathway, there were $106 \mathrm{FLS} 2$ genes, 88 upregulated and 18 downregulated; 7 Rboh genes, 5 upregulated and 2 downregulated; 5 upregulated CDPK genes; 5 CNGC genes, 3 upregulated and 2 downregulated; and 57 GST genes in the glutathione metabolism pathway, 49 upregulated and 8 downregulated (Fig. 5). These genes were related to the metabolism of reactive oxygen species (ROS) and $\mathrm{Ca}^{2+}$. In the MAPK signalling pathway-plant pathway, 304 DEGs regulated 30 crucial points related to $\mathrm{ROS}, \mathrm{Ca}^{2+}$, abscisic acid (ABA), ethylene (ET), jasmonic acid (JA), $\mathrm{H}_{2} \mathrm{O}_{2}$ and $\mathrm{FLS} 2$. In the flavonoid biosynthesis pathway, the genes encoding chalcone synthase (CHS) and ferulate-5-hydroxylase ( $\mathrm{F} 5 \mathrm{H})$ were induced. In the phenylpropanoid biosynthesis pathway, the key genes $P A L$ and $4 C L$ were also induced. 
The GO enrichment analysis revealed that the 5638 genes were mainly enriched in 86 terms, including the intrinsic component of membrane, integral component of membrane, membrane part, membrane, catalytic activity, response to biotic stimulus, cell wall, oxidoreductase activity, defence response, response to stimulus, response to stress, and response to fungus (Q-value $<0.001$ ), and the first 15 terms are listed in Table 2. Of the 16 genes in the response to fungus term, 15 were upregulated and 1 was downregulated. The GO classification showed that there were 18, 14 and 12 terms in biological process, cellular component and molecular function, respectively, and the KEGG classification indicated that the DEGs mainly belonged to the metabolism pathway (2856 DEGs).

\section{DEGs co-induced by CEF-082 and $V$. dahliae}

There were 463 shared DEGs at $12 \mathrm{~h}$ and $48 \mathrm{~h}$ (Fig. 6) that were significantly enriched in 6 KEGG pathways (Table 3 ). In the plant-pathogen interaction pathway, 29 DEGs regulated 8 crucial points, including CNGCs, calmodulin (CaM), FLS2, RPS2, HSP90, Pti1, RPM1, and EIX1/2. In the phenylpropanoid biosynthesis pathway, 23 DEGs regulated 9 crucial points. In the flavonoid biosynthesis pathway, 12 DEGs regulated 8 crucial points. The enriched GO terms included terpenoid metabolic process, oxidoreductase activity, defence response, hydrogen peroxide metabolic process and reactive oxygen species metabolic process terms.

\section{DEGs specifically induced by CEF-082}

A total of 1209 specific DEGs were identified at $12 \mathrm{~h}$ and $48 \mathrm{~h}$ after removing all of the shared DEGs in the three stages in the control group, and the cluster thermogram showed the expression patterns of these genes at different stages (Fig. 7). KEGG classification showed that these DEGs mainly belonged to metabolism (672 DEGs) and were significantly enriched in 5 KEGG pathways, including flavonoid biosynthesis, indole alkaloid biosynthesis, MAPK signalling pathway-plant, plant-pathogen interaction, and phenylpropanoid biosynthesis (Table 4). GO classification showed that there were 14, 12 and 9 terms in the biological process, cellular component and molecular function, respectively. GO enrichment indicated that these DEGs were enriched in reactive oxygen species metabolic process (14 DEGs), hydrogen peroxide metabolic process (12 DEGs), hydrogen peroxide catabolic process (12 DEGs), defence response (31 DEGs), superoxide dismutase activity (5 DEGs), antioxidant activity (19 DEGs), oxidoreductase activity, acting on superoxide radicals as acceptor (5 DEGs), cofactor binding (75 DEGs) and DNA binding (121 DEGs) (Fig. S2).

At $12 \mathrm{~h}$ and $48 \mathrm{~h}, 96$ shared DEGs were obtained by eliminating the shared DEGs in the CK at different stages (Fig. 8). KEGG analysis of the 96 DEGs indicated that they were mainly enriched in glutathione metabolism and flavonoid biosynthesis (Table 5). GO analysis showed that the DEGs were enriched in superoxide dismutase activity, oxidoreductase activity, acting on superoxide radicals as acceptors, and antioxidant activity terms. Of the 96 DEGs, there were 9 transcription factors (TFs) and 20 plant resistance genes (PRGs) (Table S4). 


\section{Putative R genes and TFs involved in the resistance to Verticillium wilt}

Based on the transcriptome analysis, a total of 65 candidate genes were identified that may be related to the resistance of cotton to Verticillium wilt, including 5 CNLs, 3 CNs, 5 NLs, 7 RLPs, 7 Ns, 9 TNLs, 6 Ts, 1 Mlo-like and 2 other types. These genes mainly included a disease resistance protein, 2 probable calciumbinding protein (CML45), 3 ethylene-responsive transcription factor (ERF), 2 cyclic nucleotide-gated ion channel 2 (CNGC2), 5 MYB TFs and 2 glutathione S-transferase (GST) (Table 6-1, Table 6-2, and Table 6-3). Clustering thermogram of 65 genes was made (Fig. 9), and the results showed that certain genes were upregulated at 0,12 and $48 \mathrm{~h}$; certain genes were downregulated at $0 \mathrm{~h}$, while upregulated at 12 and $48 \mathrm{~h}$; certain genes were downregulated at 0,12 and $48 \mathrm{~h}$.

\section{Protein interaction network induced by CEF-082}

A protein-protein interaction network (Fig. 10) was obtained by using the 96 DEGs shared at 12 and $48 \mathrm{~h}$ and genes interacting with them in cotton. Six hub genes were obtained: Gh_A05G1020, Gh_D09G0858, BGI_novel_G004376, Gh_A08G0125, Gh_D07G1197, and Gh_A05G3508. Among them, Gh_D07G1197 was enriched in the flavonoid biosynthesis pathway.

\section{Discussion}

The number of DEGs identified at $12 \mathrm{~h}$ and $48 \mathrm{~h}$ was lower than that identified at $0 \mathrm{~h}$. It has been suggested that the number of DEGs decreased because both plants were infected with $V$. dahliae and began to respond defensively. For CEF-082 treatment and CEF-082+ V. dahliae treatment, DEGs were mainly enriched in 5 signalling pathways, plant-pathogen interaction, MAPK signalling pathway-plant, flavonoid biosynthesis, phenylpropanoid biosynthesis, and glutathione metabolism. The pathways of plant-pathogen interaction and flavonoid biosynthesis were also induced in sunflower infected with $V$. dahliae [13], and the results were also consistent with those of Tan [18], who reported that most DEGs in tomato were associated with phenylpropanoid metabolism and plant-pathogen interaction pathways. However, the glutathione metabolism pathway has rarely been reported in the transcriptome of cotton plants treated with $V$. dahliae.

DEGs related to ET, SA, JA, brassinosteroid (BR) and cytokinin were upregulated or downregulated upon $V$. dahliae infection in cotton [3]. In this study, we also found that DEGs in ABA, auxin and gibberellin were significantly induced not only after treatment with CEF-082 but also after inoculation with $V$. dahliae. The 8 plant hormones were also induced after infection with $V$. dahliae in sunflower [13]. The responses of the A. thaliana auxin receptors TIR1, AFB1 and AFB3 and auxin transporter AXR4 were impaired upon infection with $V$. dahliae [19]. Therefore, both CEF-082 and $V$. dahliae can induce changes in hormones.

Previously, it was shown that after plants were infected with pathogens, the FLS2 pattern recognition receptors recognized pathogens, and the hypersensitive response (HR) was activated through ROS, JA, 
WRKYs and the NO signalling pathways [20-21] and mediated by CNGC, RBOH, CaM/CML and FLS2 [22-24]. These results are consistent with the results from this study. In this study, $24 \mathrm{~h}$ after treatment with CEF-082, the DEGs of FLS2, Rboh, CDPK, CNGCs and GST in the plants were also upregulated or downregulated to varying degrees (Fig. 5). In addition, most of the genes coding peroxidase (POD), superoxide dismutase (SOD), and catalase (CAT) were also upregulated. These genes were related to the accumulation of ROS. Forty-eight hours after treatment with $V$. dahliae, the genes encoding CNGC, $\mathrm{CaM} / \mathrm{CML}$ and FLS2 were upregulated. However, in this study, the NO signalling pathway was not induced.

Phenylpropane synthesis is related to cotton defence mechanisms [25], while flavonoids are known were to buffer substantial stress-induced alterations in ROS homeostasis and to modulate the ROS-signalling cascade [26]. Plant CNGC subunits and CaM constitute a molecular switch that either opens or closes calcium channels [27]. Previous reports have shown that calcium-dependent CDPK4 and CDPK5 regulate ROS production by phosphorylating NADPH oxidase in potatoes [28]. ROS are important not only for signalling mechanisms for defence [29] but also for regulating programmed cell death via the establishment of the HR [30]. MAPK family members can improve resistance to Verticillium wilt in cotton [31]. In this study, $24 \mathrm{~h}$ after CEF-082 inoculation, certain signal transduction pathways may have been involved in the plant response to CEF-082 (Fig. 11). After inoculation with CEF-082, FLS2 recognized CEF-082, MAPK signal transduction was induced, and calcium channels were opened. Then, $\mathrm{H}_{2} \mathrm{O}_{2}$ was produced, leading to ROS burst. Plant hormones were also induced, including ET, SA, JA, ABA, BR, auxin, gibberellin and cytokinin. The signalling pathways of flavonoids and phenylpropane synthesis were also involved in this process. In addition, lignin synthesis was also induced after treatment with CEF-082 (Fig. 12). $\mathrm{C} 4 \mathrm{H}$ and $\mathrm{C} 3 \mathrm{H}$ were not induced in TOh-vs-COh, $\mathrm{T} 12 \mathrm{~h}-\mathrm{vs}-\mathrm{C} 12 \mathrm{~h}$, or T48h-vs-C48h but were induced in $\mathrm{C} 12 \mathrm{~h}-\mathrm{vs}-\mathrm{COh}$, which was similar to the results of Xu et al. [32], who indicated that $\mathrm{C} 4 \mathrm{H}-1$ and $\mathrm{C} 4 \mathrm{H}-3$ were upregulated after treatment with $V$. dahliae. Three days after inoculation with $V$. dahliae, lignin was detected, and the pith diameter of $\mathrm{CEF}-082+V$. dahliae-treated plants was slightly larger than that of water $+V$. dahliae-treated plants (Fig. S3). The defence response at $\mathrm{T} 12 \mathrm{~h}$ and $\mathrm{T} 48 \mathrm{~h}$ was similar to that at TOh, and only some key points induced were different in the pathways shown in Fig. 11 and Fig. 12. Thus, it is speculated that CEF-082 can control cotton Verticillium wilt because inoculation with CEF-082 can prime signalling pathways to defend against $V$. dahliae upon its infection.

When pathogens infect plants, they induce a series of defence responses. GST participates in plant defences and can remove ROS [34]. Plant GSTs can be subdivided into eight categories, phi, zeta, tau, theta, lambda, dehydroascorbate reductase (DHAR), elongation factor 1 gamma (EF1G) and tetrachlorohydroquinone dehalogenase (TCHQD) [35]. GSTF8 was used as a marker in early stress and defence responses [36], and salicylic acid, methyl jasmonate, $A B A$ and $\mathrm{H}_{2} \mathrm{O}_{2}$ can induce GST expression [37-39]. LrGSTU5 was obviously upregulated after treatment with Fusarium oxysporum [40], and the GST genes were also upregulated in G. barbadense treated with $V$. dahliae [41]. In this study, the GST genes were also significantly induced $24 \mathrm{~h}$ after treatment with CEF-082 (Fig. 5), and GST genes were upregulated in cotton treated with Water $+V$. dahliae. These results are consistent with those of Han et al. 
and Zhang et al. [40-41]. Certain GST genes were also significantly induced in the treatment group but were not significantly induced in the control group after treatment with $V$. dahliae. The GST gene Gh_A09G1509 enhanced resistance against Verticillium wilt in tobacco [42]. Hence, we suggest that CEF082 can induce specific GST genes to protect cotton from $V$. dahliae.

V. dahliae can induce a defence response after it infects cotton [3]. In this study, susceptible cotton varieties were inoculated with the biocontrol fungus CEF-082 and $V$. dahliae, which also induced a series of defence responses. Compared with plants inoculated with water $+V$. dahliae, the plants inoculated with $\mathrm{CEF}-082+V$. dahliae had significantly upregulated or downregulated expression levels of resistancerelated genes. Therefore, it is speculated that the defence response was strengthened after inoculation with the biocontrol fungus CEF-082. In addition, we obtained 1209 specific DEGs, which could not be induced in plants inoculated with water $+V$. dahliae, and GO enrichment showed that these genes were involved in the metabolic process of ROS. The disease resistance of cotton was enhanced after CEF-082 treatment, and thus, we inferred that these specific DEGs might be genes related to plant disease resistance.

\section{Conclusion}

CEF-082 can induce defensive responses in cotton, and pretreated with CEF-082 with appropriate concentration $10^{5} \mathrm{CFU} / \mathrm{mL}$ can improve the resistance of cotton (Jimian 11) to Verticillium wilt. Transcriptome analysis revealed that genes in cotton leaves involved in ROS burst, $\mathrm{Ca}^{2+}$, lignin biosynthesis, flavonoids and phenylpropane synthesis were significantly upregulated or downregulated. In this study, the transcriptome was used to study the expression of genes in cotton when CEF-82 and $V$. dahliae coexisted, which provided a basis for understanding the mechanism by which biocontrol fungi prevent Verticillium wilt in cotton.

\section{Abbreviations}

FLS2: LRR receptor-like serine/threonine-protein kinase FLS2; Rboh: respiratory burst oxidase; CDPK: calcium-dependent protein kinase. CYP: Cytochrome P450 proteins.

\section{Declarations}

\section{Acknowledgements}

We thank members of Professor Zhu's groups for technical assistance, financial support and helpful discussions.

\section{Funding}


This work was supported by National Key Research and Development Program of China (2017YFD0201900) and National Natural Science Foundation of China (31901938). We thank all the foundation of economic support. The funding organizations provided the financial support to the research projects, and involved in the design of the study.

\section{Authors' contributions}

YZ, LZ, HZ and CT conceived the study. YZ and NY performed the experiments. YZ analysed the results and wrote the manuscript, with feedback from all authors. All authors have read and approved the manuscript.

\section{Availability of data and materials}

Most data supporting the results and conclusions are included in the article and additional files.

\section{Ethics declarations}

\section{Ethics approval and consent to participate}

Not applicable.

\section{Consent for publication}

Not applicable.

\section{Competing interests}

The authors declare that they have no competing interests.

\section{References}

1. Tian J, Zhang XY, Liang BG. Expression of baculovirus anti-apoptotic genes p35 and op-iap in cotton (Gossypium hirsutum L.) enhances tolerance to Verticillium wilt. Plos One. 2010; 5(12): e14218】

2. Sun Q, Jiang HZ, Zhu XY, Wang WN, He XH, Shi YZ, Yuan YL, Du XM and Cai YF. Analysis of seaisland cotton and upland cotton in response to Verticillium dahliae infection by RNA sequencing. BMC Genomics. 2013; 14:852.

3. Zhang WW, Zhang HC, Liu K, Jian GL, Qi FJ, Si N. Large-scale identification of Gossypium hirsutum genes associated with Verticillium dahliae by comparative transcriptomic and reverse genetics 
analysis. Plos One. 2017; 12(8):e0181609.

4. Wang YQ, Liang CZ, Wu SJ, Zhang XY, Tang JY, Jian GL, Jiao GL, Li FG, Chu CC. Significant improvement of cotton Verticillium wilt resistance by manipulating the expression of Gastrodia antifungal proteins. Molecular Plant. 2016; 9(10):1436-1439.

5. Zhang Y, Wang XF, Rong W, Yang J, Li ZK, Wu LQ, Zhang GY, Ma ZY. Histochemical analyses reveal that stronger intrinsic defenses in Gossypium barbadense than in $\mathrm{G}$. hirsutum are associated with resistance to Verticillium dahliae. Molecular Plant-Microbe Interactions. 2017; 30(12): 984-996.

6. Han Q, Wu FL, Wang XN, Qi H, Shi L, Ren A, Liu QH, Zhao MW, Tang CM. The bacterial lipopeptide iturins induce Verticillium dahliae cell death by affecting fungal signalling pathways and mediate plant defence responses involved in pathogen-associated molecular pattern-triggered immunity. Environmental Microbiology. 2015; 17(4):1166-1188.

7. Li ZF, Wang LF, Feng ZL, Zhao LH, Shi YQ, Zhu HQ. Diversity of endophytic fungi from different Verticillium-wilt-resistant Gossypium hirsutum and evaluation of antifungal activity against Verticillium dahliae in vitro. Journal of Microbiology \& Biotechnology. 2014; 24(9):1149-61.

8. Veloso J and Díaz J. Fusarium oxysporum Fo47 confers protection to pepper plants against Verticillium dahliae and Phytophthora capsici, and induces the expression of defence genes. Plant Pathology. 2012; 61(2):281-288.

9. Tjamos SE, Emmanouil F, Epaminondas JP, Panagiotis K. Induction of resistance to Verticillium dahliae in Arabidopsis thaliana by the biocontrol agent K-165 and pathogenesis-related proteins gene expression. Molecular Plant-Microbe Interactions. 2005; 18(6):555-561.

10. Ding T, Su B, Chen XJ, Xie SS, Gu SY, Wang Q, Huang DY, Jiang HY. An endophytic bacterial strain isolated from eucommia ulmoides inhibits Southern Corn Leaf Blight. Frontiers in Microbiology. $2017 ; 8: 903$.

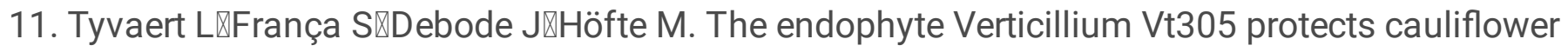
against Verticillium wilt. Journal of Applied Microbiology. 2014, 116: 1563-1571区

12. Su XF, Lu GQ, Guo HM, Zhang KX, Li XK, Cheng HM. The dynamic transcriptome and metabolomics profiling in Verticillium dahliae inoculated Arabidopsis thaliana. Scientific Reports. 2018; 8(1):1-11.

13. Guo SC, Zuo YC, Zhang YF, Wu CY, Su WX, Jin W, Yu HF, An YL, Li QZ. Large-scale transcriptome comparison of sunflower genes responsive to Verticillium dahliae. BMC Genomics. 2017; 18(1):42.

14. Zhang YL囚Li ZF®Feng ZL, Feng HJ, Zhao LH, Shi YQ, Hu XP, Zhu HQ. Isolation and functional analysis of the pathogenicity-related gene VdPR3 from Verticillium dahliae on cotton $₫$ Current Genetics. 2015; 61(4): 555-566ه

15. Zhang ZY, Zhang X, Hu ZB, Wang SF, Zhang JB, Wang XJ, Wang QL, Zhang BH. Lack of K-dependent oxidative stress in cotton roots following coronatine-induced ROS accumulation. Plos One. 2015; 10(5):p.e0126476.

16. Sharma A, Thakur S, Kumar V, Kesavan AK, Thukral AK, Bhardwaj R. 24-epibrassinolide stimulates imidacloprid detoxification by modulating the gene expression of brassica junceal. BMC Plant Biology. 2017; 17(1): 56. 
17. Zhu HQ, Feng ZL, Li ZF, Shi YQ, Zhao LH. Characterization of two fungal isolates from cotton and evaluation of their potential for biocontrol of Verticillium wilt of cotton. Journal of Phytopathology. 2013; 161(2):70-77.

18. Tan GX, Liu K, Kang JM, Xu KD, Zhang Y, Hu LZ, Zhang J, Li CW. Transcriptome analysis of the compatible interaction of tomato with Verticillium dahliae using RNA-sequencing. Frontiers in Plant Science. 2015; 6.

19. Fousiaa S, Tsafourosb A, Roussosb PA, Tjamos SE. Increased resistance to Verticillium dahliae in Arabidopsis plants defective in auxin signaling. Plant Pathology. 2018; 67: 1749-1757.

20. Yao LL, Zhou Q, Pei BL, Li YZ. Hydrogen peroxide modulates the dynamic microtubule cytoskeleton during the defence responses to Verticillium dahliae toxins in Arabidopsis. Plant, Cell and Environment. 2011;34(9):1586-1598.

21. Dang ZH, Zheng LL, Wang J, Gao Z, Wu SB, Qi Z, Wang YC. Transcriptomic profiling of the salt-stress response in the wild recretohalophyte Reaumuria trigyna. BMC Genomics. 2013; 14:29.

22. Zhang H, Yang YZ, Wang CY, Liu M, Li H, Fu Y, Wang YJ, Nie YB, Liu XL, Ji WQ. Large-scale transcriptome comparison reveals distinct gene activations in wheat responding to stripe rust and powdery mildew. BMC Genomics. 2014; 15:898.

23. Singh N, Bhatla SC. Nitric oxide and iron modulate heme oxygenase activity as a long distance signaling response to salt stress in sunflower seedling cotyledons. Nitric Oxide. 2016; 53:54-64.

24. Yadav S, David A, Baluska F, Bhatla SC. Rapid auxin-induced nitric oxide accumulation and subsequent tyrosine nitration of proteins during adventitious root formation in sunflower hypocotyls. Plant Signal Behav. 2013; 8(3):e23196.

25. Bu BW, Qiu DW, Zeng HM, Guo LH, Yuan JJ, Yang XF. A fungal protein elicitor PevD1 induces Verticillium wilt resistance in cotton. Plant Cell Rep. 2014; 33:461-470.

26. Cecilia B, Alessio F, Federico S, Antonella G, Massimiliano T. Modulation of phytohormone signaling: a primary function of flavonoids in plant-environment interactions. Frontiers in plant science. 2018; 9.

27. Pan YJ, Chai XY, Gao QF, Zhou LM, Zhang SS, Li LG, Luan S. Dynamic interactions of plant CNGC subunits and Calmodulins drive oscillatory Ca2+ channel activities. Developmental Cell. 2019; 48(5):710-725.

28. Kobayashi M, Ohura I, Kawakita K, Yokota N, Fujiwara M, Shimamoto K, Doke N, Yoshioka H. Calcium-dependent protein kinases regulate the production of reactive oxygen species by potato NADPH oxidase. Plant Cell. 2007; 19, 1065-1080.

29. Eckardt NA. The plant cell reviews plant immunity: receptor-like kinases, ROS-RLK crosstalk, quantitative resistance, and the growth/defense trade-off. Plant Cell. 2017; 29: 601-602.

30. Tamas L, Mistrik I, Huttova J, Haluskova L, Valentovicova K, Zelinova V. Role of reactive oxygen species-generating enzymes and hydrogen peroxide during cadmium, mercury and osmotic stresses in barley root tip. Planta. 2010; 231:221-231. 
31. Meng J, Gao H, Zhai WB, Shi JY, Zhang MZ, Zhang WW, Jian GL, Zhang MP, Qi FJ. Subtle regulation of cotton resistance to Verticillium wilt mediated by MAPKK family members. Plant Science. 2018; 272:235-242.

32. Xu L, Zhu LF, Tu LL, Liu LL, Yuan DJ, Jin L, Long L, Zhang XL. Lignin metabolism has a central role in the resistance of cotton to the wilt fungus Verticillium dahliae as revealed by RNA-Seq-dependent transcriptional analysis and histochemistry. Journal of Experimental Botany. 2011; 62(15):56075621.

33. Miedes E, Vanholme R, Boerjan W, Molina A. The role of the secondary cell wall in plant resistance to pathogens. Frontiers in Plant Science. 2014; 5.

34. Chan C, Lam HM. A putative lambda class glutathione S-transferase enhances plant survival under salinity stress. Plant and Cell Physiology. 2014; 55(3):570-579.

35. Wang Z, Huang SZ, Jia CH, Liu JH, Zhang JB, Xu BY, Jin ZQ. Molecular cloning and expression of five glutathione S-transferase (GST) genes from Banana (Musa acuminata L. AAA group, cv. Cavendish). Chinese Journal of Tropical Agriculture. 2013; 32(9):1373-1380.

36. Thatcher LF, Kamphuis LG, Hane JK, Onate-Sánchez L, Singh KB. The Arabidopsis KH-domain RNAbinding protein ESR1 functions in components of jasmonate signalling, unlinking growth restraint and resistance to stress. Plos One. 2015; 10:e0126978.

37. Dixon DP, Lapthorn A, Edwards R. Plant glutathione transferases. Genome Biology. 2002; 3:1-10.

38. Dixon DP, Davis BG, Edwards R. Functional divergence in the glutathione transferase superfamily in plants. The Journal of Biological Chemistry. 2002; 277(34):30859-30869.

39. Moons A. Regulatory and functional interaction of plant growth regulators and plant glutathione Stransferases (GSTs). Vitam Horm. 2005; 72:155-202.

40. Han Q, Chen R, Yang Y, Cui XM, Ge F, Chen CY, Liu DQ. A glutathione S -transferase gene from Lilium regale Wilson confers transgenic tobacco resistance to Fusarium oxysporum. Scientia Horticulturae. 2016; 198:370-378.

41. Zhang Y, Wang XF, Ding ZG, Ma Q, Zhang GR, Zhang SL, Li ZK, Wu LQ, Zhang GY, Ma ZY. Transcriptome profiling of Gossypium barbadense inoculated with Verticillium dahliae provides a resource for cotton improvement. BMC Genomics. 2013; 14: 637.

42. Li ZK, Chen B, Li XX, Wang JP, Zhang Y, Wang XF, Yan YY, Ke HP, Yang J, Wu JH, et al. A newly identified cluster of glutathione S-transferase genes provides Verticillium wilt resistance in cotton. Plant Journal. 2019; 98(2): 213-227.

\section{Tables}

Table 1 KEGG Pathway enrichment of 5638 DEGs 


\begin{tabular}{clccc}
\hline Pathway ID & \multicolumn{1}{c}{ Pathway } & Number of DEGs & $P$-value & Q-value \\
\hline ko04626 & Plant-pathogen interaction & 376 & $2.57 \mathrm{E}-51$ & $3.47 \mathrm{E}-49$ \\
ko04016 & MAPK signalling pathway-plant & 304 & $2.77 \mathrm{E}-25$ & $1.87 \mathrm{E}-23$ \\
ko00941 & Flavonoid biosynthesis & 57 & $4.37 \mathrm{E}-08$ & $1.97 \mathrm{E}-06$ \\
ko00940 & Phenylpropanoid biosynthesis & 135 & $1.80 \mathrm{E}-07$ & $6.06 \mathrm{E}-06$ \\
ko00052 & Galactose metabolism & 88 & $6.14 \mathrm{E}-06$ & 0.000166 \\
ko00590 & Arachidonic acid metabolism & 34 & $2.09 \mathrm{E}-05$ & 0.000469 \\
ko00906 & Carotenoid biosynthesis & 39 & 0.000109 & 0.002102 \\
ko00480 & Glutathione metabolism & 68 & 0.000138 & 0.002331 \\
ko00909 & Sesquiterpenoid and triterpenoid biosynthesis & 21 & 0.000332 & 0.004976 \\
ko00591 & Linoleic acid metabolism & 22 & 0.000788 & 0.010643 \\
ko00511 & Other glycan degradation & 42 & 0.001074 & 0.013183 \\
ko00604 & Glycosphingolipid biosynthesis - ganglio series & 27 & 0.001366 & 0.015371 \\
ko00905 & Brassinosteroid biosynthesis & 15 & 0.001554 & 0.016135 \\
ko00904 & Diterpenoid biosynthesis & 36 & 0.003500 & 0.033752 \\
ko00600 & Sphingolipid metabolism & 44 & 0.004324 & 0.038919 \\
\hline
\end{tabular}

Pathways with a Q-value $<0.05$ are shown.

Table 2 GO enrichment of 5638 DEGs

\begin{tabular}{ccccc}
\hline Term ID & Term & Number of DEGs & $P$-value & Q-value \\
\hline GO:0031224 & intrinsic component of membrane & 1494 & $2.76 \mathrm{E}-26$ & $6.24 \mathrm{E}-23$ \\
GO:0016021 & integral component of membrane & 1486 & $6.55 \mathrm{E}-25$ & $7.42 \mathrm{E}-22$ \\
GO:0030246 & carbohydrate binding & 141 & $6.90 \mathrm{E}-22$ & $5.20 \mathrm{E}-19$ \\
GO:0044425 & membrane part & 1506 & $2.47 \mathrm{E}-20$ & $1.40 \mathrm{E}-17$ \\
GO:0009607 & response to biotic stimulus & 60 & $1.13 \mathrm{E}-18$ & $5.14 \mathrm{E}-16$ \\
GO:0016020 & membrane & 1542 & $4.17 \mathrm{E}-18$ & $1.57 \mathrm{E}-15$ \\
GO:0005576 & extracellular region & 152 & $8.49 \mathrm{E}-18$ & $2.74 \mathrm{E}-15$ \\
GO:0001871 & pattern binding & 60 & $2.23 \mathrm{E}-17$ & $5.60 \mathrm{E}-15$ \\
GO:0030247 & polysaccharide binding & 60 & $2.23 \mathrm{E}-17$ & $5.60 \mathrm{E}-15$ \\
GO:0005618 & cell wall & 74 & $1.50 \mathrm{E}-14$ & $3.08 \mathrm{E}-12$ \\
GO:0030312 & external encapsulating structure & 74 & $1.50 \mathrm{E}-14$ & $3.08 \mathrm{E}-12$ \\
GO:0003824 & catalytic activity & 2165 & $3.11 \mathrm{E}-14$ & $5.86 \mathrm{E}-12$ \\
GO:0051704 & multi-organism process & 59 & $5.08 \mathrm{E}-14$ & $8.84 \mathrm{E}-12$ \\
GO:0044036 & cell wall macromolecule metabolic process & 45 & $9.14 \mathrm{E}-14$ & $1.48 \mathrm{E}-11$ \\
GO:0071554 & cell wall organization or biogenesis & 119 & $1.43 \mathrm{E}-13$ & $2.16 \mathrm{E}-11$ \\
\hline
\end{tabular}

Terms with a Q-value $<0.001$ are shown.

Table 3 KEGG pathway enrichment of 463 DEGs 


\begin{tabular}{|c|c|c|c|c|}
\hline Pathway ID & Pathway & Number of DEGs & $P$-value & Q-value \\
\hline ko00940 & Phenylpropanoid biosynthesis & 23 & $4.25 \mathrm{E}-06$ & 0.000304 \\
\hline ko00941 & Flavonoid biosynthesis & 12 & 6.33E-06 & 0.000304 \\
\hline ko00052 & Galactose metabolism & 17 & $1.06 \mathrm{E}-05$ & 0.000339 \\
\hline ko04626 & Plant-pathogen interaction & 29 & 0.000725 & 0.011595 \\
\hline ko00232 & Caffeine metabolism & 3 & 0.001058 & 0.014514 \\
\hline ko00909 & Sesquiterpenoid and triterpenoid biosynthesis & 5 & 0.001558 & 0.018699 \\
\hline
\end{tabular}

Pathways with corrected- $p$ (Q-value) $<0.05$ are shown.

Table 4 KEGG pathway enrichment of 1209 DEGs

\begin{tabular}{clccc}
\hline Pathway ID & Pathway & Number of DEGs & $P$-value & Q-value \\
\hline ko00941 & Flavonoid biosynthesis & 19 & 0.000016 & 0.002007 \\
ko00901 & Indole alkaloid biosynthesis & 14 & 0.000042 & 0.002610 \\
ko04016 & MAPK signalling pathway - plant & 60 & 0.000474 & 0.019427 \\
ko04626 & Plant-pathogen interaction & 59 & 0.001099 & 0.033788 \\
ko00940 & Phenylpropanoid biosynthesis & 34 & 0.001932 & 0.047538 \\
\hline
\end{tabular}

Pathways with corrected-p (Q-value) $<0.05$ are shown.

Table 5 KEGG Pathway enrichment of 96 DEGs

\begin{tabular}{clcll}
\hline Pathway ID & Pathway & Number of DEGs & $P$-value & Q-value \\
\hline ko00480 & Glutathione metabolism & 5 & 0.001184 & 0.035893 \\
ko00941 & Flavonoid biosynthesis & 4 & 0.001496 & 0.035893 \\
\hline
\end{tabular}

Pathways with a $Q$-value $<0.05$ are shown.

Table 6-1 Predicted R genes induced by CEF-082 and $V$. dahliae 


\begin{tabular}{|c|c|c|c|c|}
\hline Transcript ID & Type & $\begin{array}{l}\text { log2-Fold } \\
\text { Change }(12 \\
\text { h) }\end{array}$ & $\begin{array}{l}\text { log2-Fold } \\
\text { Change }(48 \\
\text { h) }\end{array}$ & Nr Functional Annotation \\
\hline Gh_A01G0315 & CNL & 1.037589939 & 1.4113336 & $\begin{array}{l}\text { disease resistance protein At4g27190-like, } \\
\text { partial [Gossypium hirsutum] }\end{array}$ \\
\hline Gh_A08G1253 & CNL & -6.740709401 & 5.746950454 & kelch repeat type 1 [Corchorus capsularis] \\
\hline Gh_D02G0329 & CNL & -5.561290274 & 4.673143293 & $\begin{array}{l}\text { probable glutathione S-transferase } \\
\text { [Gossypium hirsutum] }\end{array}$ \\
\hline Gh_D07G2361 & CNL & 1.502212669 & -4.237409783 & $\begin{array}{l}\text { hypothetical protein B456_001G187600 } \\
\text { [Gossypium raimondii] }\end{array}$ \\
\hline Gh_D11G2274 & CNL & -1.125013164 & -1.176243053 & $\begin{array}{l}\text { AAA-ATPase At1g43910-like [Gossypium } \\
\text { hirsutum] }\end{array}$ \\
\hline Gh_A04G0855 & $\mathrm{CN}$ & 5.289214165 & 4.734256842 & $\begin{array}{l}\text { uncharacterized protein LOC108457923 } \\
\text { isoform X2 [Gossypium arboreum] }\end{array}$ \\
\hline Gh_D09G1718 & $\mathrm{CN}$ & 1.293119787 & 1.144955552 & $\begin{array}{l}\text { uncharacterized protein LOC } 105800125 \\
\text { [Gossypium raimondii] }\end{array}$ \\
\hline Gh_Sca089655G01 & $\mathrm{CN}$ & -1.657997189 & -1.535872284 & $\begin{array}{l}\text { uncharacterized protein LOC107949870 } \\
\text { [Gossypium hirsutum] }\end{array}$ \\
\hline Gh_A06G1937 & $\begin{array}{l}\text { Mlo- } \\
\text { like }\end{array}$ & 1.358973461 & 1.345179474 & MLO-like protein 2 [Gossypium hirsutum] \\
\hline Gh_A01G2142 & NL & -1.561586712 & -1.020990318 & $\begin{array}{l}\text { NAC domain-containing protein 90-like } \\
\text { [Gossypium arboreum] }\end{array}$ \\
\hline Gh_A09G1261 & NL & 2.484985295 & 2.969406864 & $\begin{array}{l}\text { E3 ubiquitin-protein ligase PUB23-like } \\
\text { [Gossypium hirsutum] }\end{array}$ \\
\hline Gh_A09G1326 & NL & -1.010963189 & 1.6799656 & $\begin{array}{l}\text { B3 domain-containing protein At2g36080-like } \\
\text { [Gossypium arboreum] }\end{array}$ \\
\hline Gh_D08G1656 & NL & -5.969729954 & -5.677096641 & $\begin{array}{l}\text { MOB kinase activator-like } 1 \mathrm{~A} \text { isoform X1 } \\
\text { [Gossypium hirsutum] }\end{array}$ \\
\hline Gh_D11G3107 & NL & 3.221799962 & -4.647807823 & $\begin{array}{l}\text { uncharacterized protein LOC107925949 } \\
\text { [Gossypium hirsutum] }\end{array}$ \\
\hline Gh_A01G0470 & $\mathrm{N}$ & 8.54387182 & 10.19853857 & $\begin{array}{l}\text { putative RING-H2 finger protein ATL19 } \\
\text { [Gossypium hirsutum] }\end{array}$ \\
\hline Gh_A03G1126 & $\mathrm{N}$ & 1.517931636 & 1.090903245 & $\begin{array}{l}\text { putative } \mathrm{ABC} \text { transporter } \mathrm{C} \text { family member } 15 \\
\text { [Theobroma cacao] }\end{array}$ \\
\hline Gh_A07G1963 & $\mathrm{N}$ & 1.113205106 & 1.574240958 & $\begin{array}{l}\text { ABC transporter B family member 19-like } \\
\text { isoform X1 [Gossypium hirsutum] }\end{array}$ \\
\hline Gh_D09G0181 & $\mathrm{N}$ & -1.254590611 & 1.59727426 & $\begin{array}{l}\text { ABC transporter B family member } 19 \\
\text { [Gossypium arboreum] }\end{array}$ \\
\hline Gh_D09G1048 & $\mathrm{N}$ & -1.254965579 & 1.436429867 & $\begin{array}{l}\text { ABC transporter } \mathrm{G} \text { family member 23-like } \\
\text { [Gossypium hirsutum] }\end{array}$ \\
\hline Gh_D11G0790 & $\mathrm{N}$ & 6.846798953 & 7.786264797 & $\begin{array}{l}\text { putative casein kinase II subunit beta- } 4 \\
\text { [Gossypium hirsutum] }\end{array}$ \\
\hline Gh_D11G3289 & $\mathrm{N}$ & -3.221611506 & 1.159392828 & $\begin{array}{l}\text { ABC transporter } \mathrm{G} \text { family member } 20 \text {-like } \\
\text { [Gossypium hirsutum] }\end{array}$ \\
\hline Gh_A01G0355 & RLP & 1.257686713 & 1.389731263 & $\begin{array}{l}\text { LRR receptor-like serine/threonine-protein } \\
\text { kinase GSO1 [Gossypium arboreum] }\end{array}$ \\
\hline Gh_D01G0066 & RLP & 2.472710792 & -1.905542187 & $\begin{array}{l}\text { hypothetical protein B456_002G007800 } \\
\text { [Gossypium raimondii] }\end{array}$ \\
\hline Gh_D01G0386 & RLP & 1.338494948 & 1.470239195 & $\begin{array}{l}\text { probable LRR receptor-like serine/threonine- } \\
\text { protein kinase At3g47570 isoform X1 } \\
\text { [Gossypium hirsutum] }\end{array}$ \\
\hline
\end{tabular}

Table 6-2 Predicted R genes induced by CEF-082 and $V$. dahliae 


\begin{tabular}{|c|c|c|c|c|}
\hline Transcript ID & Type & $\begin{array}{c}\text { log2-Fold } \\
\text { Change (12 } \\
\text { h) } \\
\end{array}$ & $\begin{array}{c}\text { log2-Fold } \\
\text { Change (48 } \\
\text { h) } \\
\end{array}$ & Nr Functional Annotation \\
\hline Gh_D05G3613 & RLP & -3.636894741 & -1.070068403 & $\begin{array}{l}\text { flavonol sulfotransferase-like [Gossypium } \\
\text { hirsutum] }\end{array}$ \\
\hline Gh_D05G3615 & RLP & 3.336220891 & 2.121111678 & $\begin{array}{l}\text { hypothetical protein B456_009G443300 } \\
\text { [Gossypium raimondii] }\end{array}$ \\
\hline Gh_D05G3699 & RLP & 3.056269729 & 4.673541612 & kinesin KP1-like [Gossypium raimondii] \\
\hline Gh_D08G1871 & RLP & 1.08210341 & 1.06909527 & $\begin{array}{l}\text { probable LRR receptor-like serine/threonine- } \\
\text { protein kinase At1g34110 [Gossypium hirsutum] }\end{array}$ \\
\hline Gh_A10G2072 & TNL & 1.586976576 & 1.014417675 & $\begin{array}{l}\text { TMV resistance protein N-like [Gossypium } \\
\text { hirsutum] }\end{array}$ \\
\hline Gh_A11G2091 & TNL & 1.199688858 & 1.260578514 & $\begin{array}{l}\text { transcription repressor MYB5-like [Gossypium } \\
\text { arboreum] }\end{array}$ \\
\hline Gh_D01G0539 & TNL & -3.861003635 & 1.878860421 & MYB-related protein 330 [Gossypium hirsutum] \\
\hline Gh_D01G1550 & TNL & 1.22796154 & 1.351072869 & lipase [Corchorus capsularis] \\
\hline Gh_D07G2090 & TNL & -1.58798514 & -1.255994867 & $\begin{array}{l}\text { MYB transcription factor MYB30 [Gossypium } \\
\text { hirsutum] }\end{array}$ \\
\hline Gh_D08G0256 & TNL & -3.281882012 & 1.421995876 & $\begin{array}{l}\text { transcription repressor MYB6-like [Gossypium } \\
\text { hirsutum] }\end{array}$ \\
\hline Gh_D09G1659 & TNL & 2.803942312 & 1.245838921 & $\begin{array}{l}\text { MYB-related protein 308-like [Gossypium } \\
\text { hirsutum] }\end{array}$ \\
\hline Gh_D10G2351 & TNL & 6.829614248 & 1.155493756 & $\begin{array}{l}\text { TMV resistance protein N-like isoform X2 } \\
\text { [Gossypium hirsutum] }\end{array}$ \\
\hline Gh_D11G0336 & TNL & 1.925007761 & 1.072893447 & MYB-related protein 306 [Gossypium hirsutum] \\
\hline Gh_A06G1144 & $\mathrm{T}$ & 1.922712186 & 1.745773435 & $\begin{array}{l}\text { ethylene-responsive transcription factor 4-like } \\
\text { [Gossypium hirsutum] }\end{array}$ \\
\hline Gh_A12G1620 & $\mathrm{T}$ & -1.404115121 & 1.637338509 & $\begin{array}{l}\text { NAC domain-containing protein 100-like } \\
\text { [Gossypium hirsutum] }\end{array}$ \\
\hline Gh_D01G0514 & $\mathrm{T}$ & 1.231975072 & 1.260531662 & $\begin{array}{l}\text { NAC domain-containing protein 72-like [Gossypium } \\
\text { hirsutum] }\end{array}$ \\
\hline Gh_D06G1403 & $\mathrm{T}$ & 1.291258193 & 1.247681127 & $\begin{array}{l}\text { ethylene-responsive transcription factor 4-like } \\
\text { [Gossypium hirsutum] }\end{array}$ \\
\hline Gh_D10G1537 & $\mathrm{T}$ & 2.276313579 & 4.332088904 & $\begin{array}{l}\text { ethylene-responsive transcription factor 1B-like } \\
\text { [Gossypium raimondii] }\end{array}$ \\
\hline Gh_D12G2494 & $\mathrm{T}$ & -1.419500468 & 1.382825786 & $\begin{array}{l}\text { putative dehydration responsive element binding } \\
\text { protein [Gossypium hirsutum] }\end{array}$ \\
\hline Gh_A03G2044 & Other & 1.343265394 & -1.171383404 & thaumatin-like protein [Gossypium arboreum] \\
\hline Gh_D11G2998 & Other & 2.626616578 & -1.757148487 & $\begin{array}{l}\text { thaumatin-like protein isoform X1 [Gossypium } \\
\text { hirsutum] }\end{array}$ \\
\hline Gh_A02G0236 & I & 2.076793222 & 1.040351538 & chalcone synthase [Vaccinium ashei] \\
\hline Gh_A04G0830 & l & 10.27309684 & 7.911807354 & $\begin{array}{l}\text { glutathione S-transferase U16-like [Gossypium } \\
\text { hirsutum] }\end{array}$ \\
\hline
\end{tabular}

Table 6-3 Predicted R genes induced by CEF-082 and $V$. dahliae 


\begin{tabular}{|c|c|c|c|c|}
\hline Transcript ID & Type & $\begin{array}{c}\text { log2-Fold } \\
\text { Change }(12 \mathrm{~h})\end{array}$ & $\begin{array}{c}\text { log2-Fold } \\
\text { Change (48 h) }\end{array}$ & Nr Functional Annotation \\
\hline Gh_A05G0560 & l & 0.753709773 & 1.881639236 & $\begin{array}{l}\text { DNA-damage-repair/toleration protein DRT100- } \\
\text { like [Gossypium raimondii] }\end{array}$ \\
\hline Gh_A05G1020 & / & 1.557304461 & 1.177105999 & $\begin{array}{l}\text { CBL-interacting serine/threonine-protein kinase } \\
\text { 25-like [Gossypium hirsutum] }\end{array}$ \\
\hline Gh_A05G3196 & / & 1.49233142 & 3.400801654 & $\begin{array}{l}\text { cyclic nucleotide-gated ion channel 2-like } \\
\text { [Gossypium arboreum] }\end{array}$ \\
\hline Gh_A05G3470 & / & -1.679248485 & 3.0042548 & $\begin{array}{l}\text { NADPH:quinone oxidoreductase-like [Gossypium } \\
\text { arboreum] }\end{array}$ \\
\hline Gh_A06G1701 & l & 1.11748676 & 1.125924709 & $\begin{array}{l}\text { shikimate O-hydroxycinnamoyltransferase-like } \\
\text { [Gossypium arboreum] }\end{array}$ \\
\hline Gh_A09G1415 & l & 2.763055805 & 1.138512634 & peroxidase 21-like [Gossypium hirsutum] \\
\hline Gh_A11G0631 & I & -1.427211837 & 1.313850285 & $\begin{array}{l}\text { probable calcium-binding protein CML } 45 \\
\text { [Gossypium hirsutum] }\end{array}$ \\
\hline Gh_A11G1367 & I & -2.131571879 & -1.430486114 & $\begin{array}{l}\text { uncharacterized protein LOC105803388 } \\
\text { [Gossypium raimondii] }\end{array}$ \\
\hline Gh_A11G3297 & / & 4.769980778 & -6.621901362 & $\begin{array}{l}\text { uncharacterized protein LOC107935227 } \\
\text { [Gossypium hirsutum] }\end{array}$ \\
\hline Gh_D02G0258 & I & -2.480311701 & -1.300029512 & receptor-like protein 12 [Gossypium hirsutum] \\
\hline Gh_D04G0409 & I & 8.681445478 & 5.183990265 & $\begin{array}{l}\text { cyclic nucleotide-gated ion channel 2-like } \\
\text { [Gossypium hirsutum] }\end{array}$ \\
\hline Gh_D05G0689 & I & 0.530244279 & 2.104072295 & $\begin{array}{l}\text { DNA-damage-repair/toleration protein DRT100 } \\
\text { [Theobroma cacao] }\end{array}$ \\
\hline Gh_D07G1197 & I & 2.197263059 & 1.546938795 & $\begin{array}{l}\text { flavonoid 3',5'-hydroxylase 2-like [Gossypium } \\
\text { hirsutum] }\end{array}$ \\
\hline Gh_D08G1512 & I & 1.61343892 & 2.05940005 & $\begin{array}{l}\text { hypothetical protein B456_002G144600 } \\
\text { [Gossypium raimondii] }\end{array}$ \\
\hline Gh_D09G0858 & I & -1.30017514 & -1.614570284 & $\begin{array}{l}\text { hypothetical protein B456_006G104900, partial } \\
\text { [Gossypium raimondii] }\end{array}$ \\
\hline Gh_D10G1431 & I & 1.879317791 & 1.074465933 & chalcone synthase [Kandelia candel] \\
\hline Gh_D11G0741 & I & -1.323988617 & 1.425564743 & $\begin{array}{l}\text { probable calcium-binding protein CML } 45 \\
\text { [Gossypium hirsutum] }\end{array}$ \\
\hline Gh_D11G1512 & I & -1.351190116 & -1.111728188 & $\begin{array}{l}\text { uncharacterized protein LOC105803388 } \\
\text { [Gossypium raimondii] }\end{array}$ \\
\hline Gh_D11G3107 & I & 3.221799962 & -4.647807823 & $\begin{array}{l}\text { uncharacterized protein LOC107925949 } \\
\text { [Gossypium hirsutum] }\end{array}$ \\
\hline
\end{tabular}

\section{Additional Files Legends}

Additional files 1: Fig. S1 Correlation thermograms of the 18 samples. (DOCX $506 \mathrm{~kb}$ )

Additional files 2: Fig. S2 GO enrichment of 1209 DEGs. (DOCX 54 kb)

Additional files 3: Fig. S3 Histochemical analysis of lignin in stem cross-sections of cotton plants. (DOCX $466 \mathrm{~kb})$

Additional files 4: Table S1 Specific primer sequences of qRT-PCR-related genes. (DOCX $15 \mathrm{~kb}$ )

Additional files 5: Table S2 Sequencing quality statistics table. (DOCX $15 \mathrm{~kb}$ )

Additional files 6: Table S3 Overview of novel transcripts. (DOCX $14 \mathrm{~kb}$ ) 
Additional files 7: Table S4 Putative R genes and TFs in 96 DEGs. (DOCX 15 kb)

Additional files 8: Data of the content of $\mathrm{H}_{2} \mathrm{O}_{2}$. (XLSX $\left.13 \mathrm{~kb}\right)$

Additional files 9: Data of disease index. (XLSX $10 \mathrm{~kb})$

Additional files 10: Data of qPCR. (XLSX $36 \mathrm{~kb})$

\section{Figures}

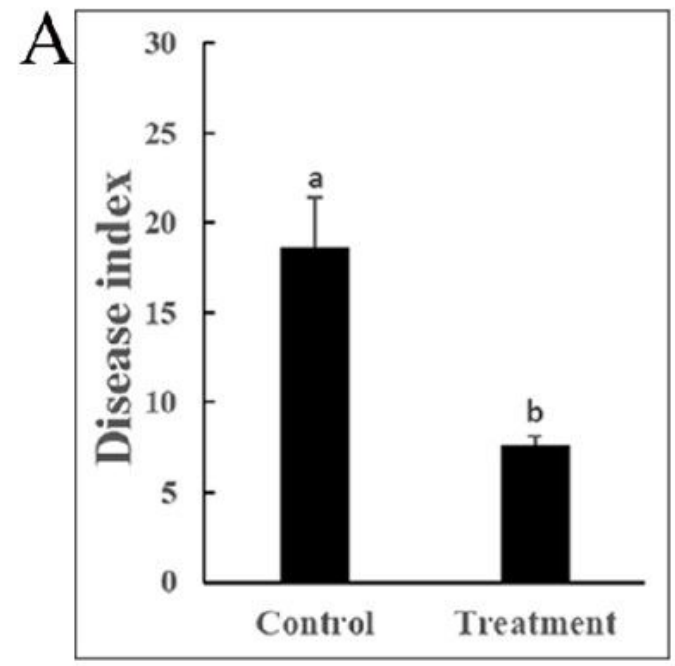

$\mathrm{B}$
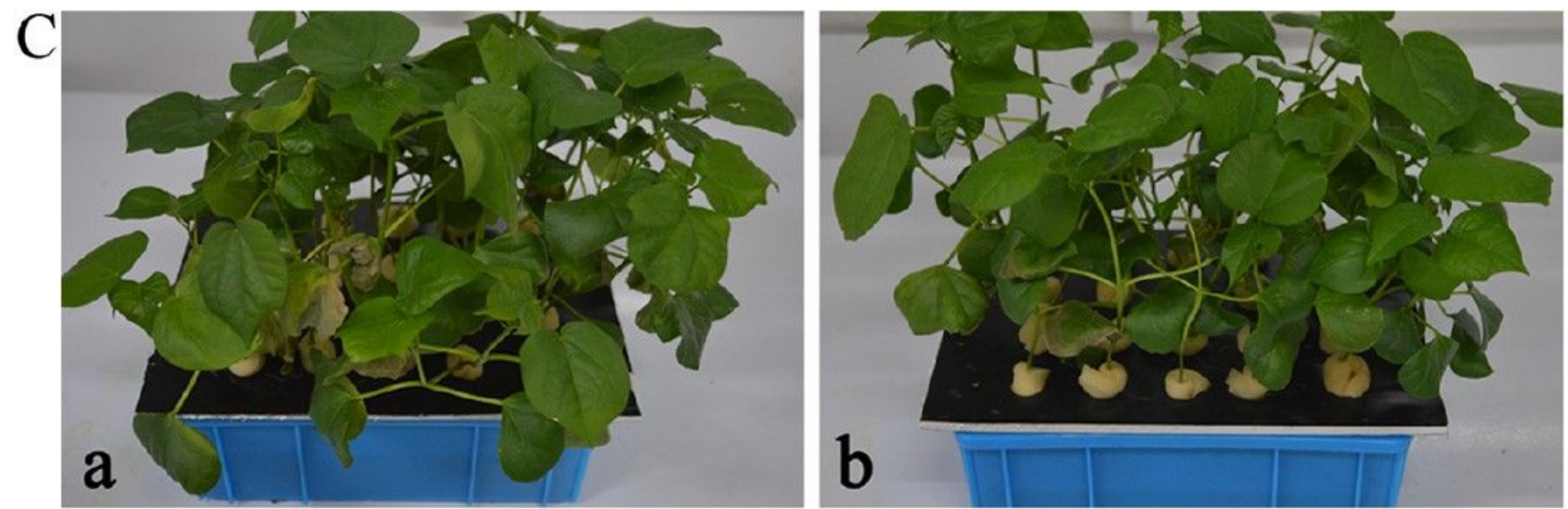

Figure 1

Disease index and symptoms of Verticillium wilt in cotton $14 \mathrm{~d}$ after V. dahliae inoculation. (A) The disease index. (B) The content of H2O2. (C) Symptoms of Verticillium wilt in cotton囚a: water+V. dahliae, b: CEF-082+V. dahliae. Bars represent SEs. 


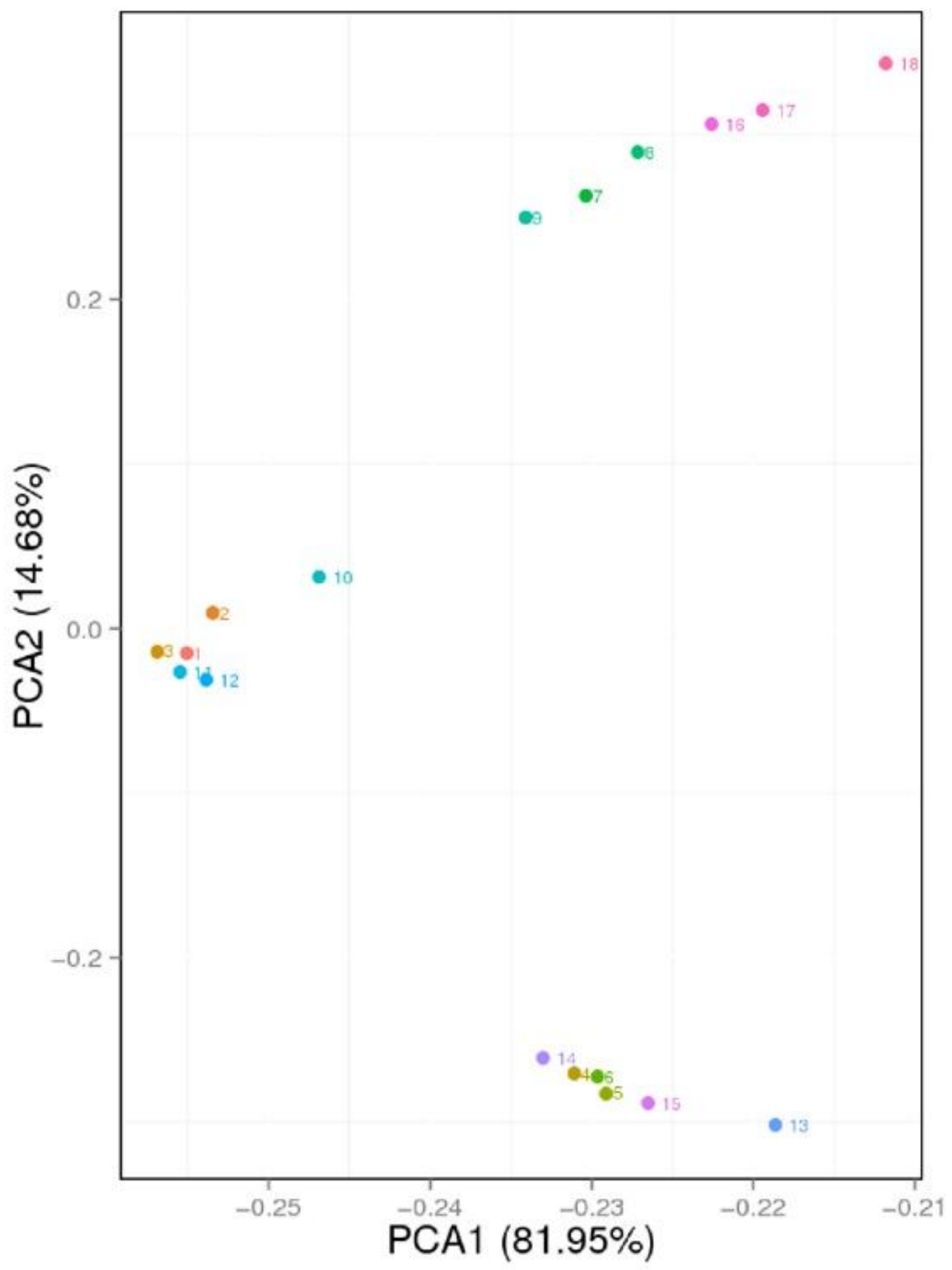

Legend

- C0h-1(1)

- C0h-2(2)

- C0h-3(3)

- C12h-1(4)

- C12h-2(5)

- C12h-3(6)

- C48h-1(7)

- C48h-2 (8)

- C48h-3 (9)

- T0h-1(10)

- T0h-2(11)

- T0h-3(12)

- T12h-1(13)

- T12h-2(14)

- T12h-3(15)

- T48h-1(16)

- T48h-2(17)

- T48h-3(18)

Figure 2

PCA of the 18 samples. 
Gh_D11G1515

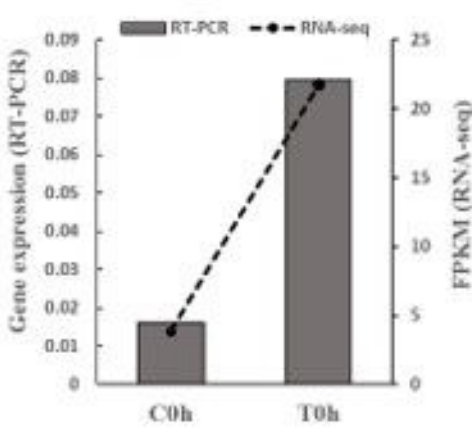

Gh DesG3615

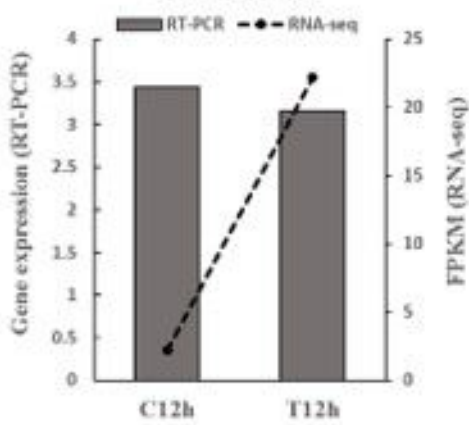

Gh_D08G2484

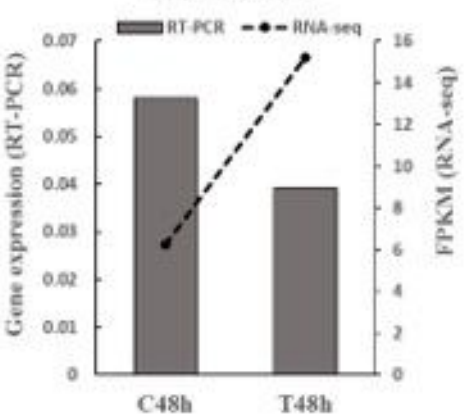

Gh De7G0457

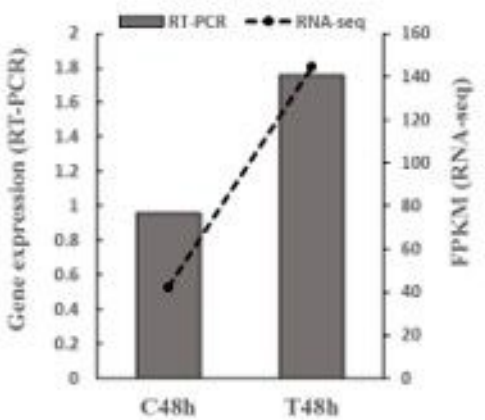

Gh_D11G1887

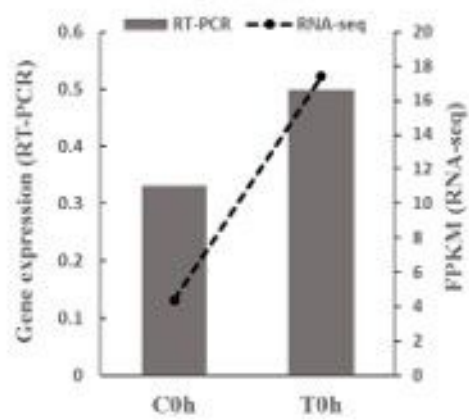

Gh A04G0855

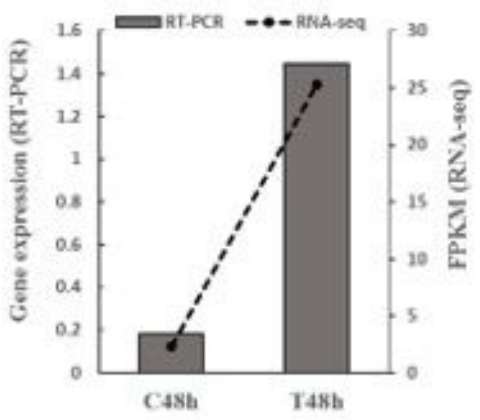

Gh_DosG0689

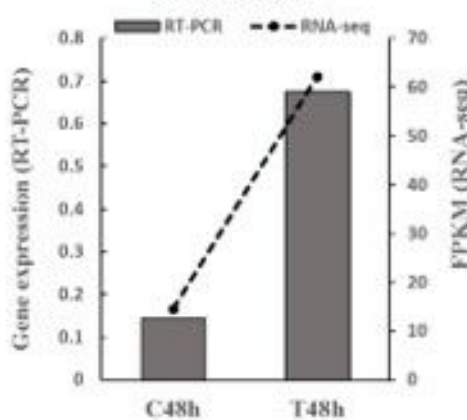

Gh_D12G2793

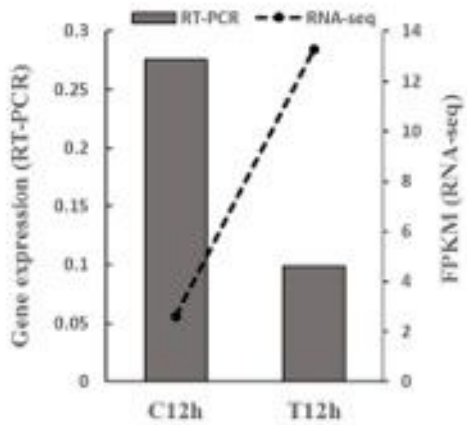

Gh_A0scos 60

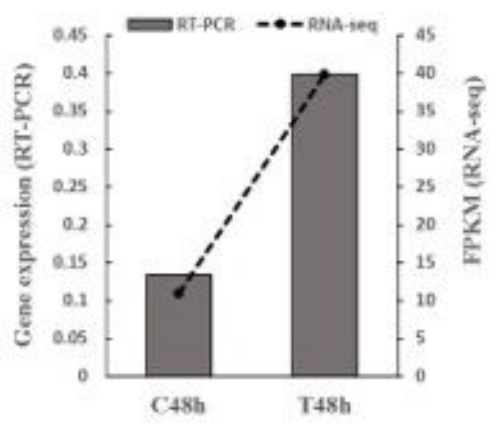

Gh D05G2642

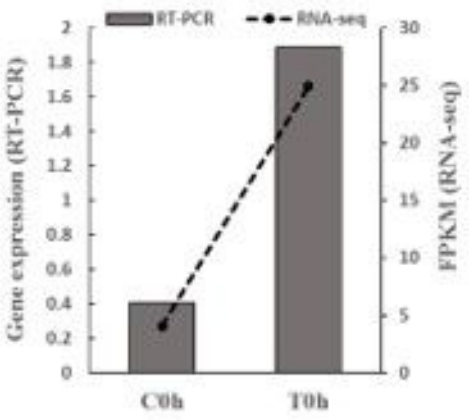

Gh_A05G0483

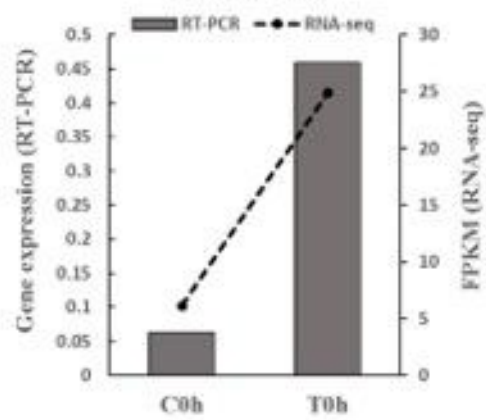

Gh De6G1832

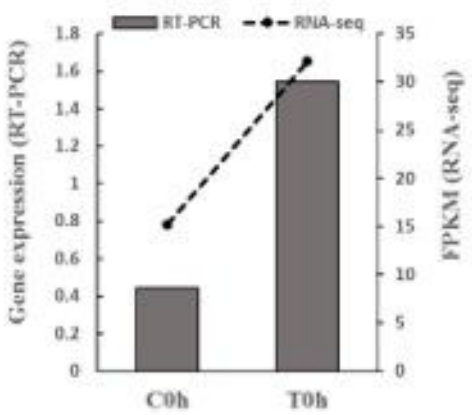

Figure 3

Comparison of the expression trends of the qRT-PCR and RNA-seq data. The grey bars represent the genes expression level relative to cotton ubiquitin gene, as an internal control, was used to normalize the expression levels of the target genes. Dotted lines represent the mean of FPKM. 


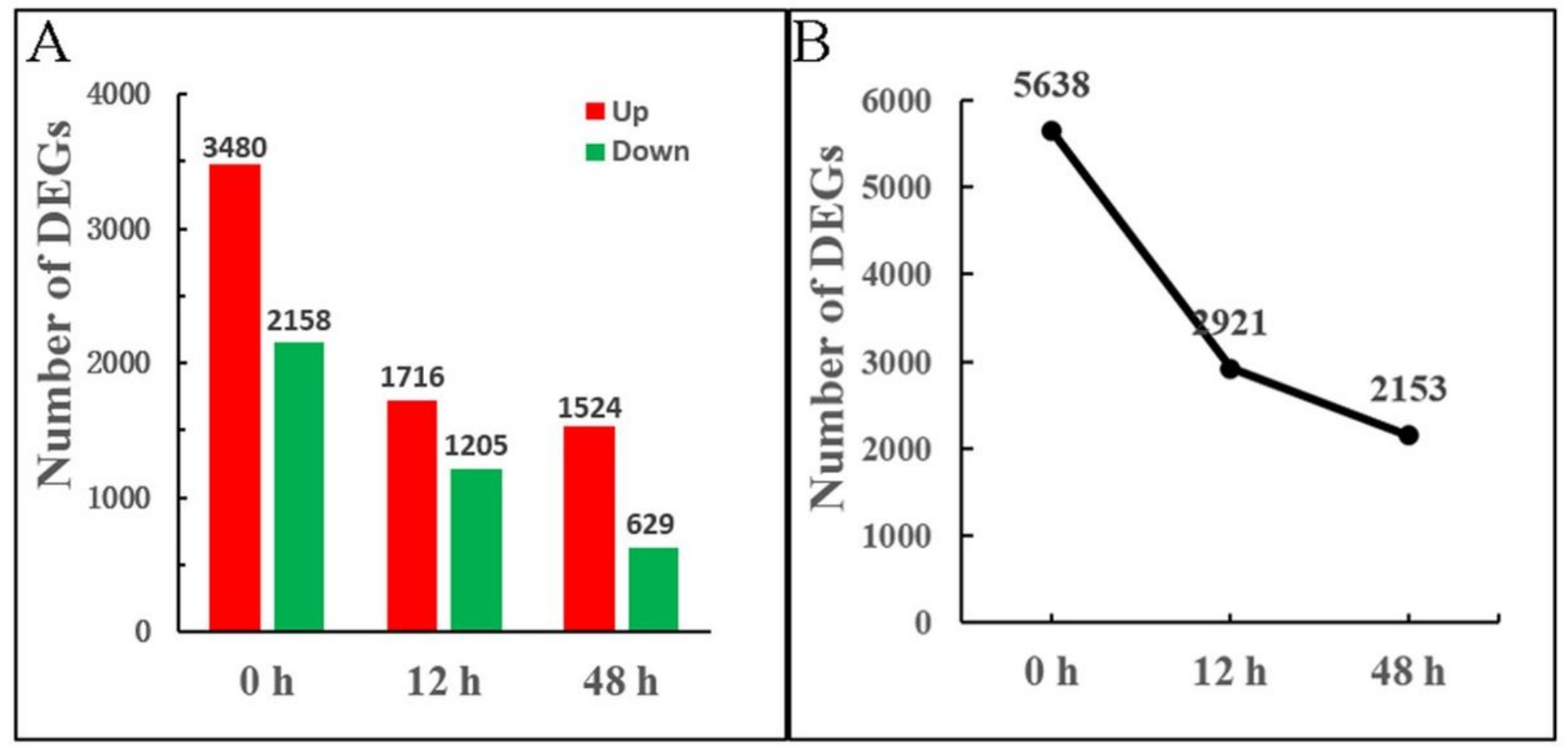

Figure 4

Number of DEGs at $0 \mathrm{~h}, 12 \mathrm{~h}$, and $48 \mathrm{~h}$. (A) Quantity of up- and downregulated genes at the three time points. (B) Total number of DEGs at the three time points. 


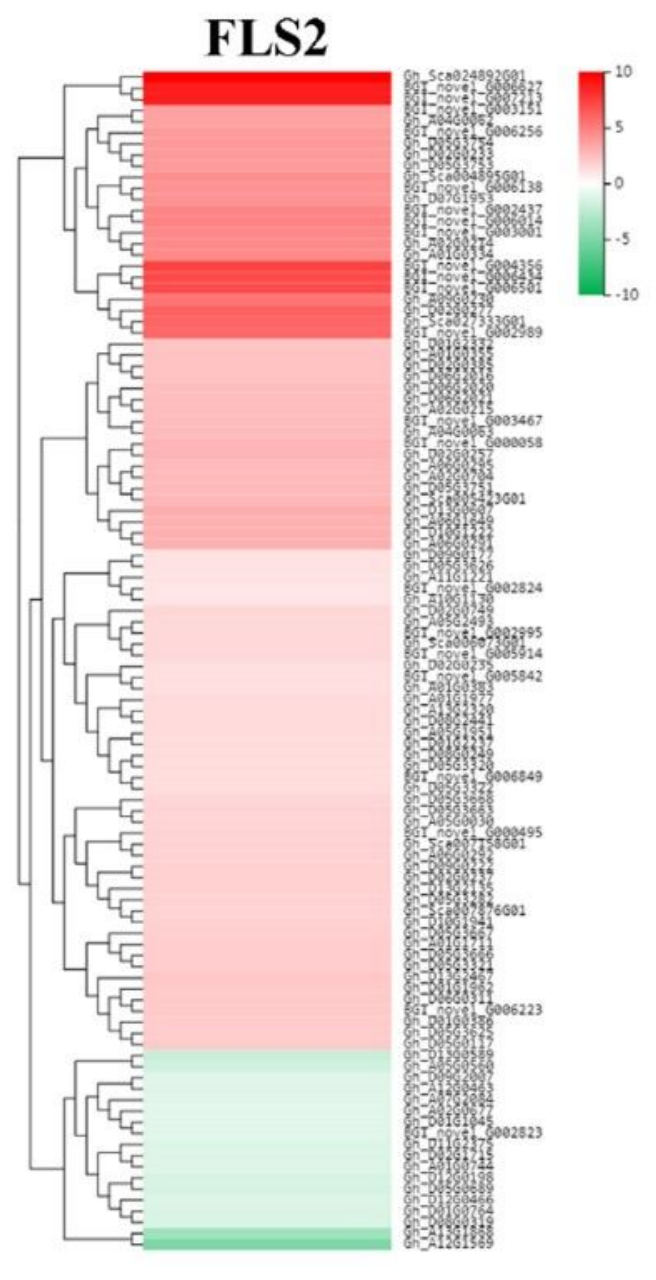

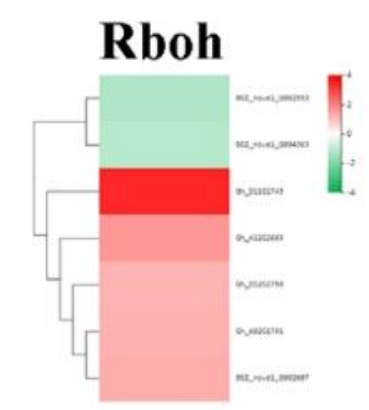

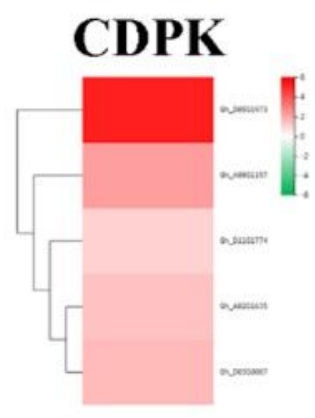

\section{CNGCs}

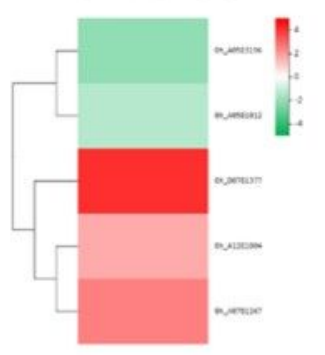

GST

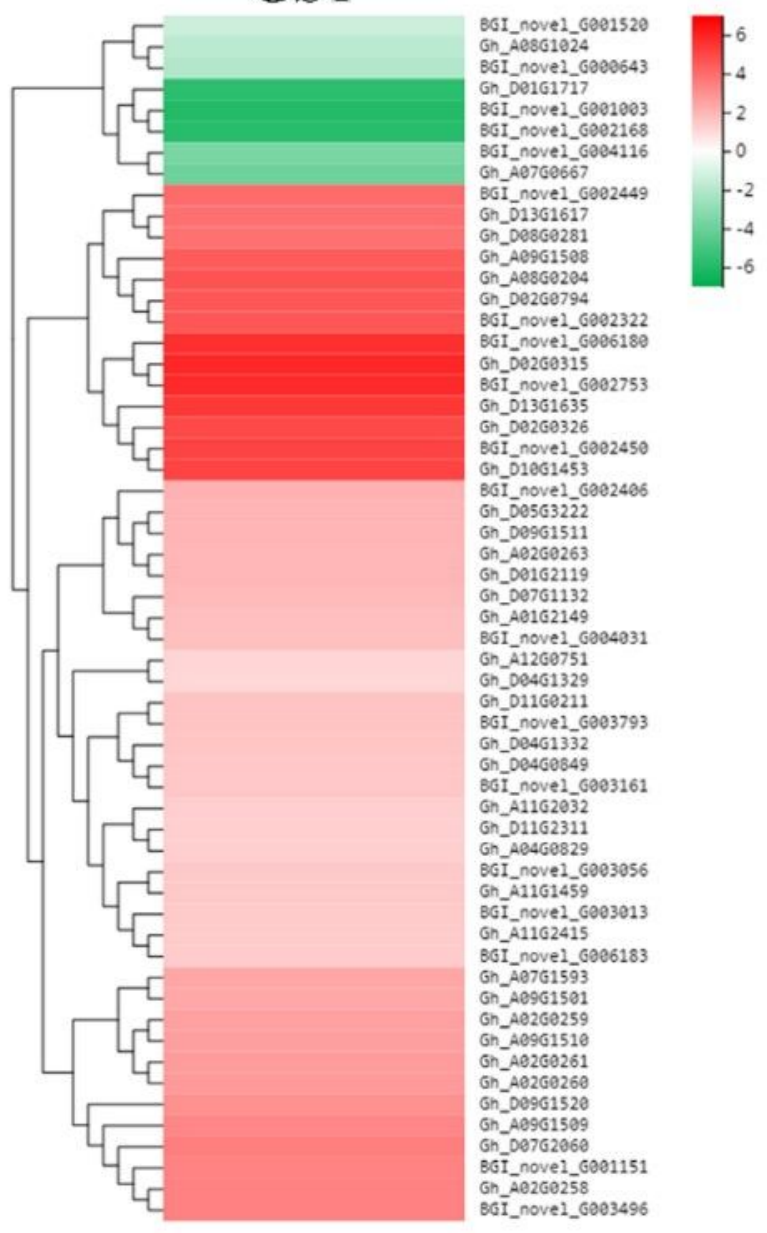

Figure 5

Expression of genes related to ROS and Ca2+. Red represents upregulation, and green represents downregulation. 


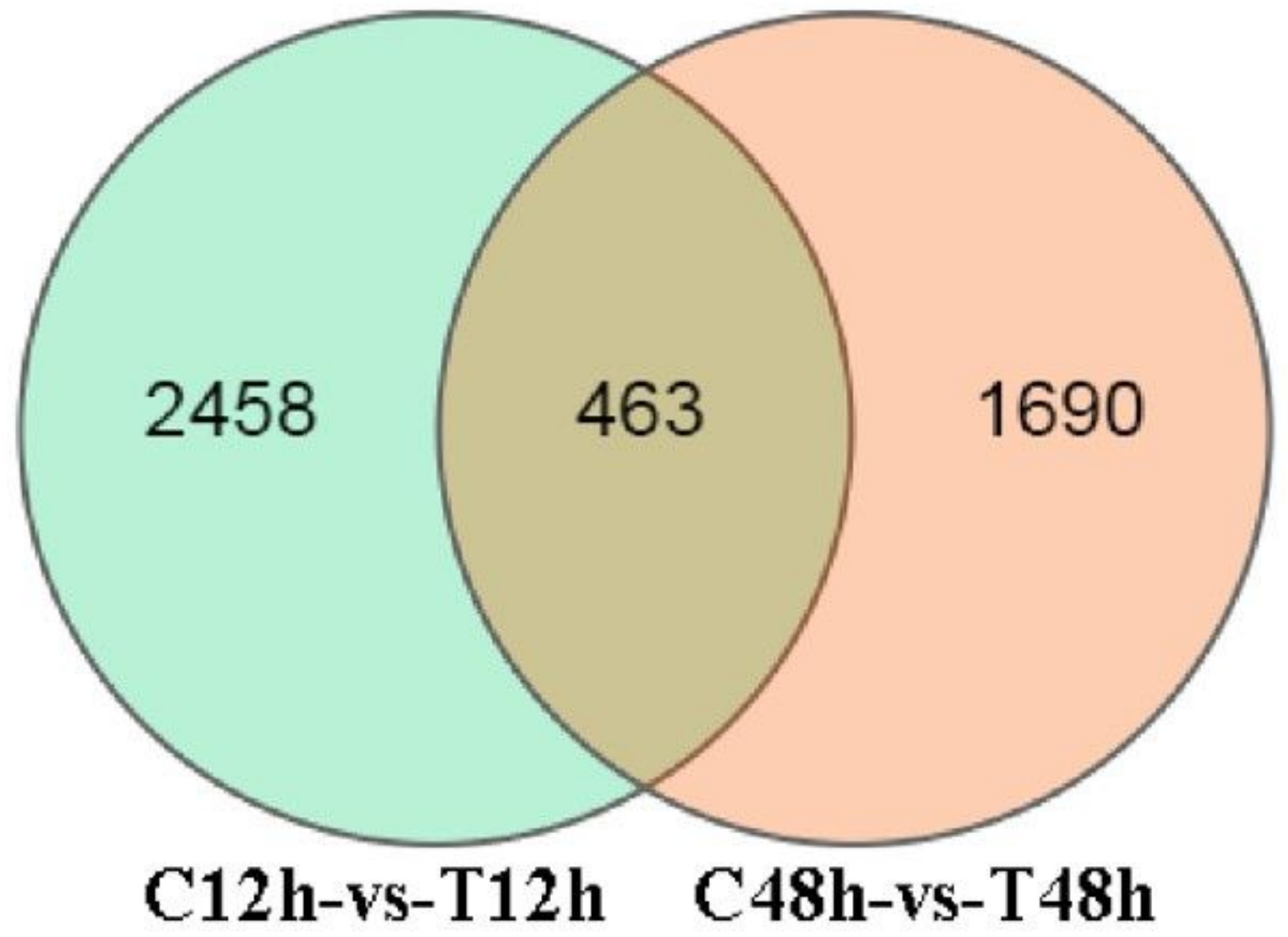

Figure 6

The distribution of DEGs $12 \mathrm{~h}$ and $48 \mathrm{~h}$ post-inoculation with V. dahliae. 


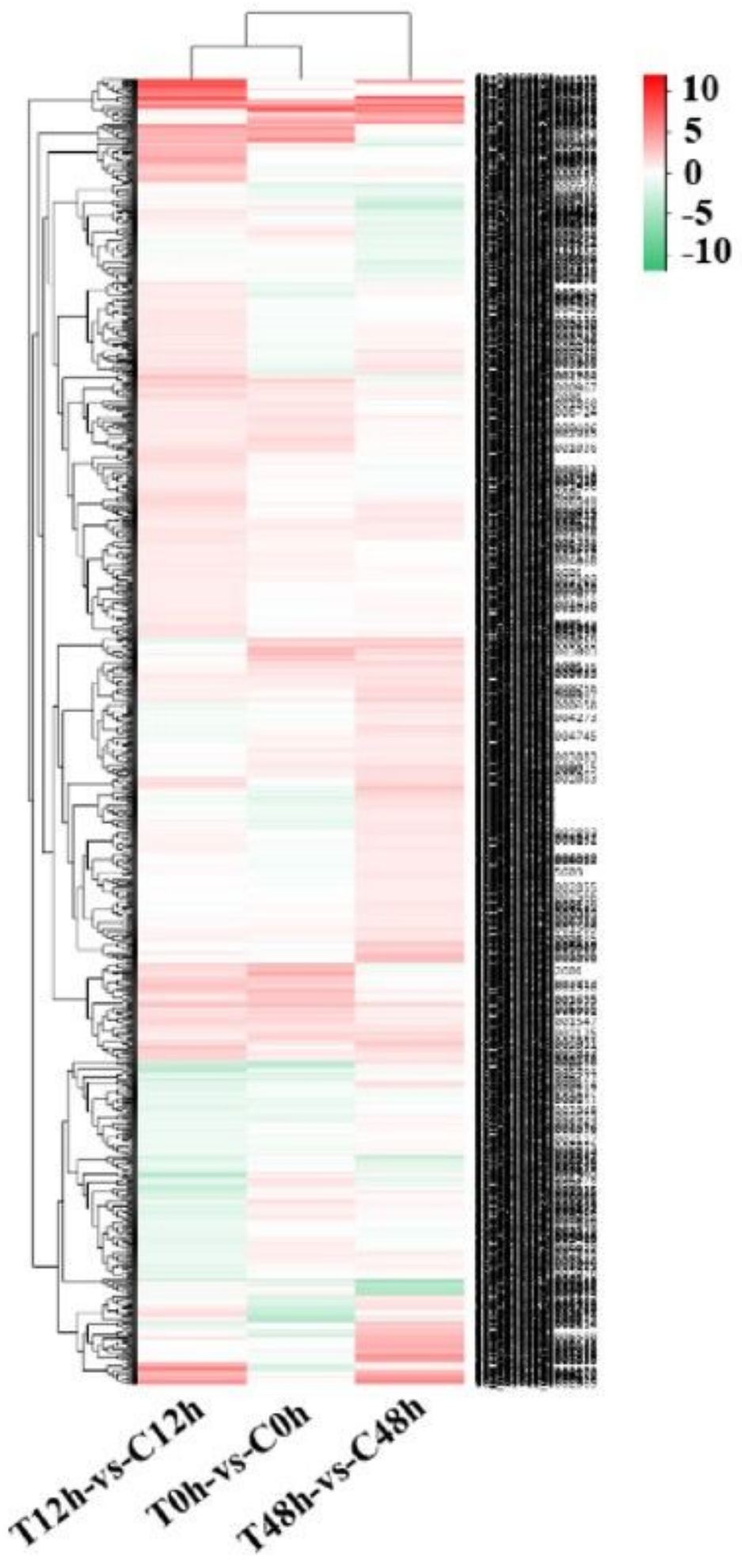

Figure 7

The clustering thermogram of 1209 DEGs. 


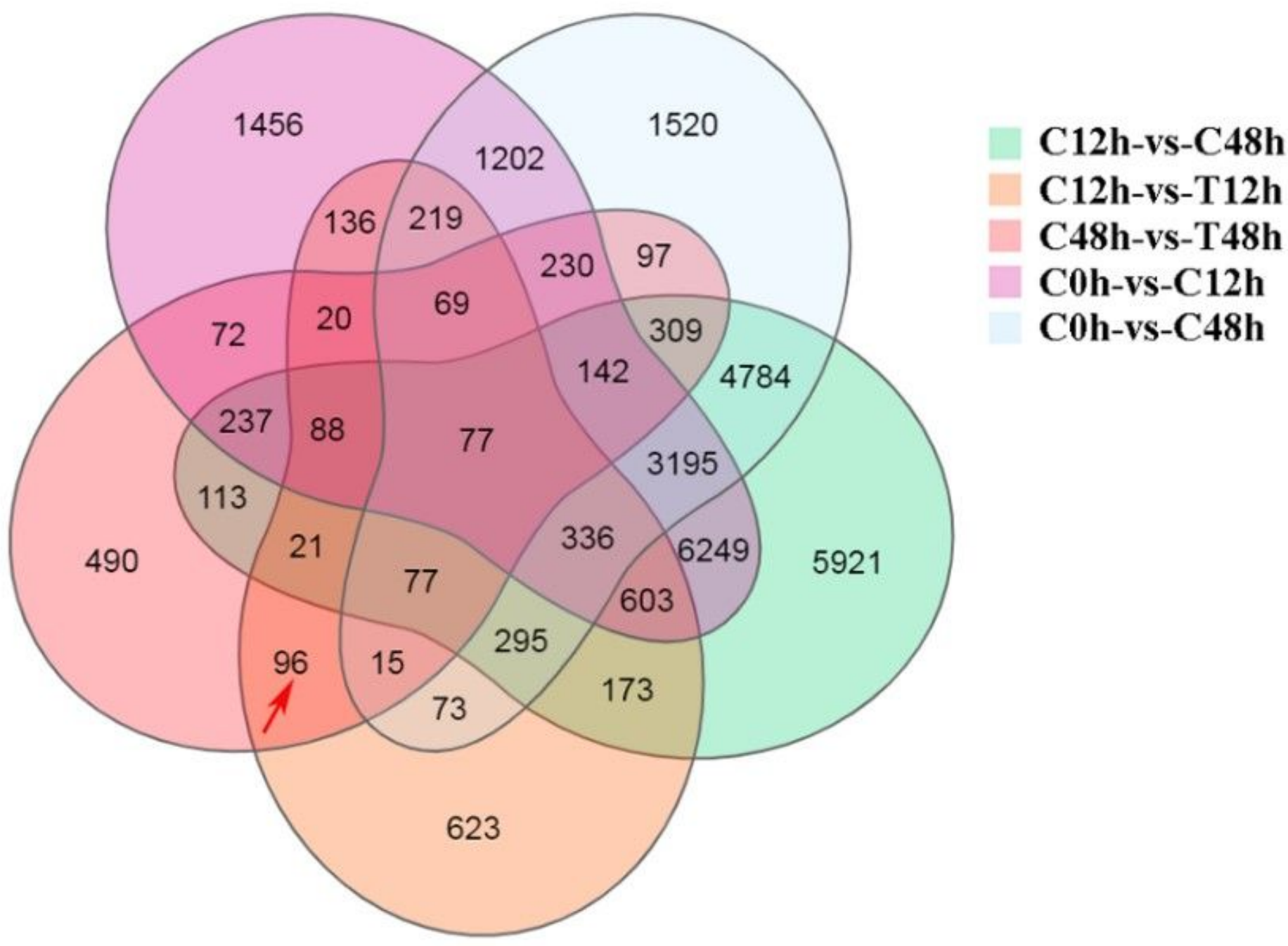

Figure 8

Venn diagram of DEGs. 


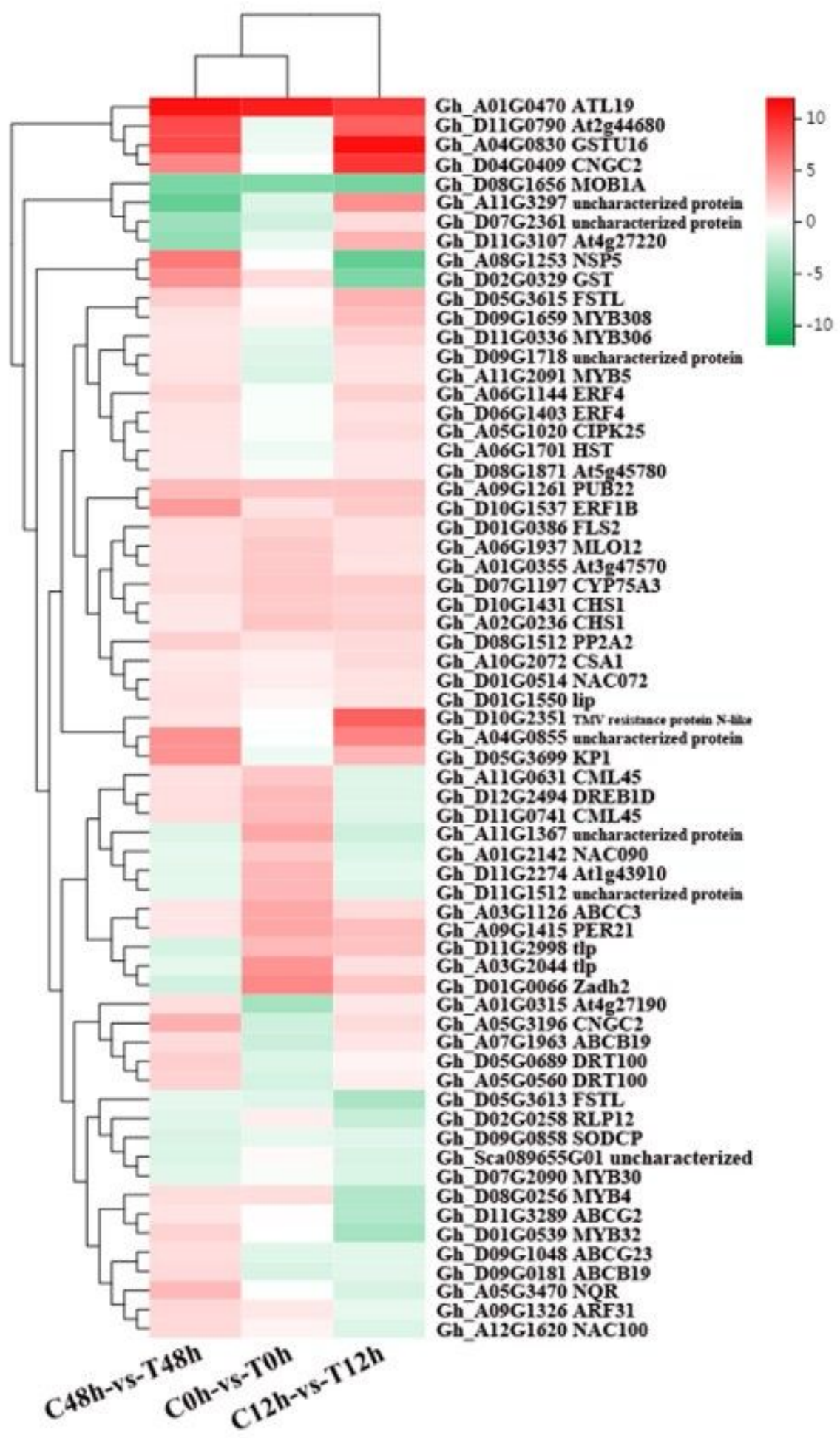

Figure 9

Clustering thermogram of putative R genes and TFs. 


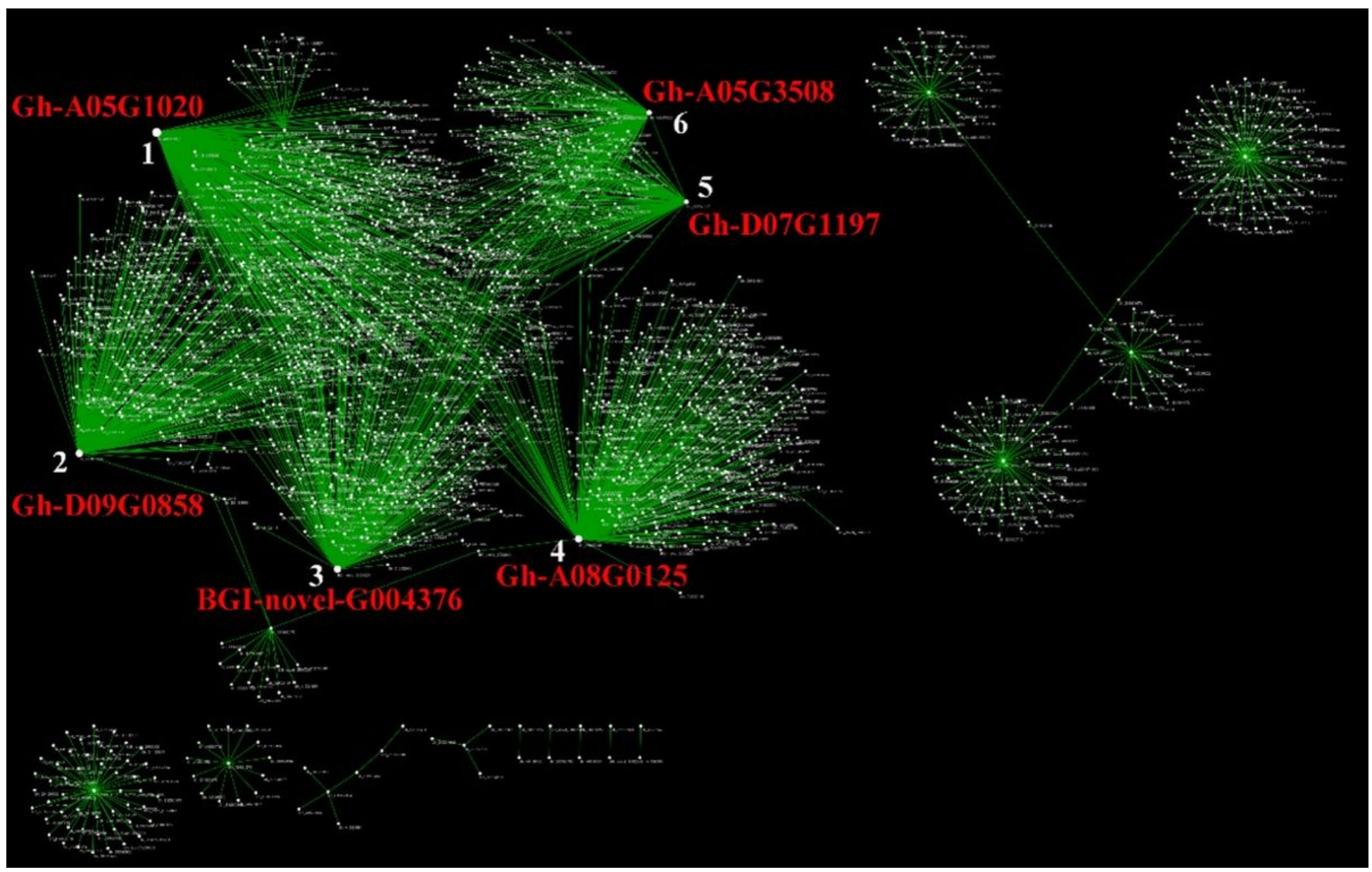

Figure 10

Protein interaction network of 96 DEGs and their related genes in cotton. The red font indicates hub genes. 


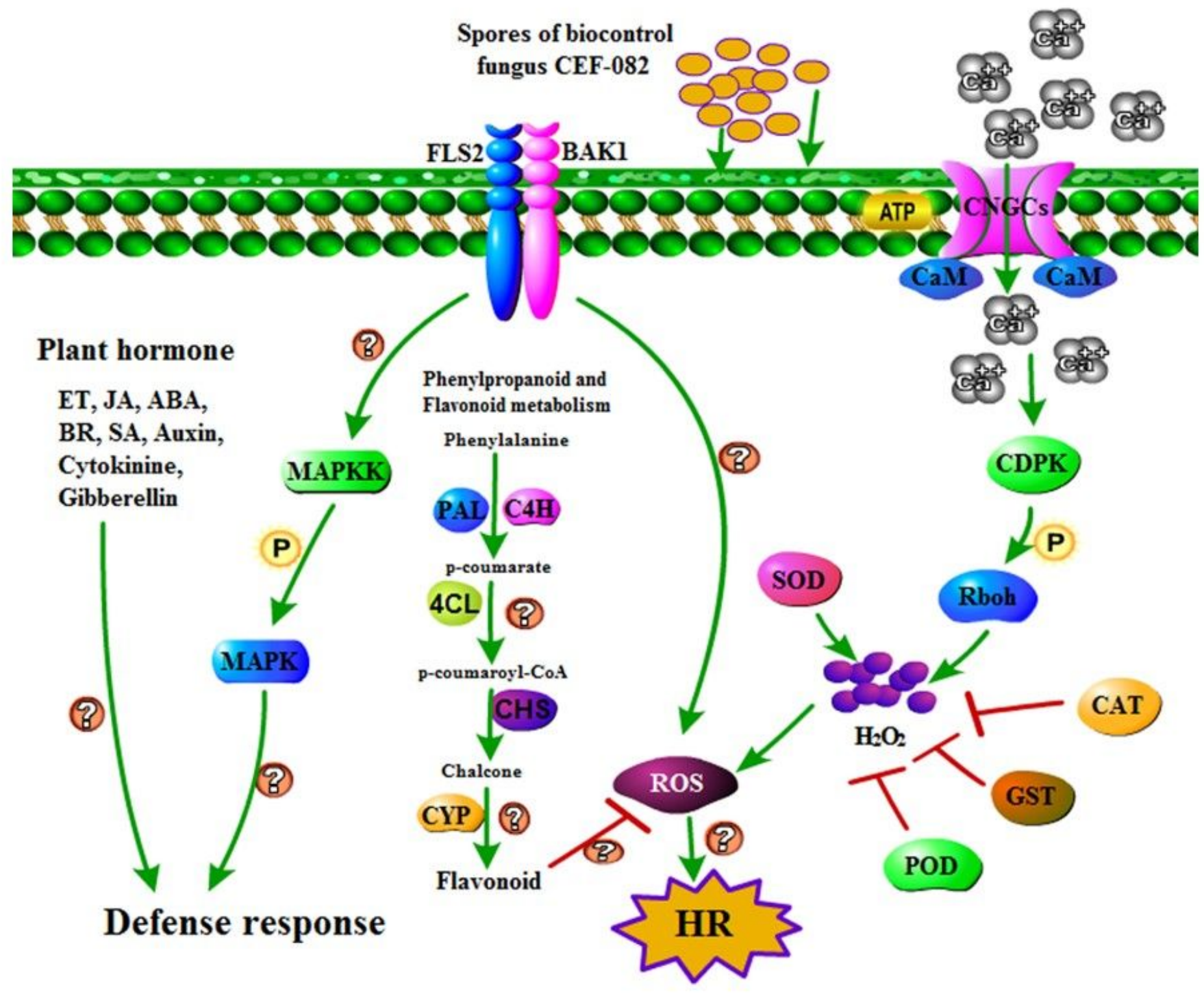

Figure 11

Signal transduction pathways induced by CEF- 082 . 


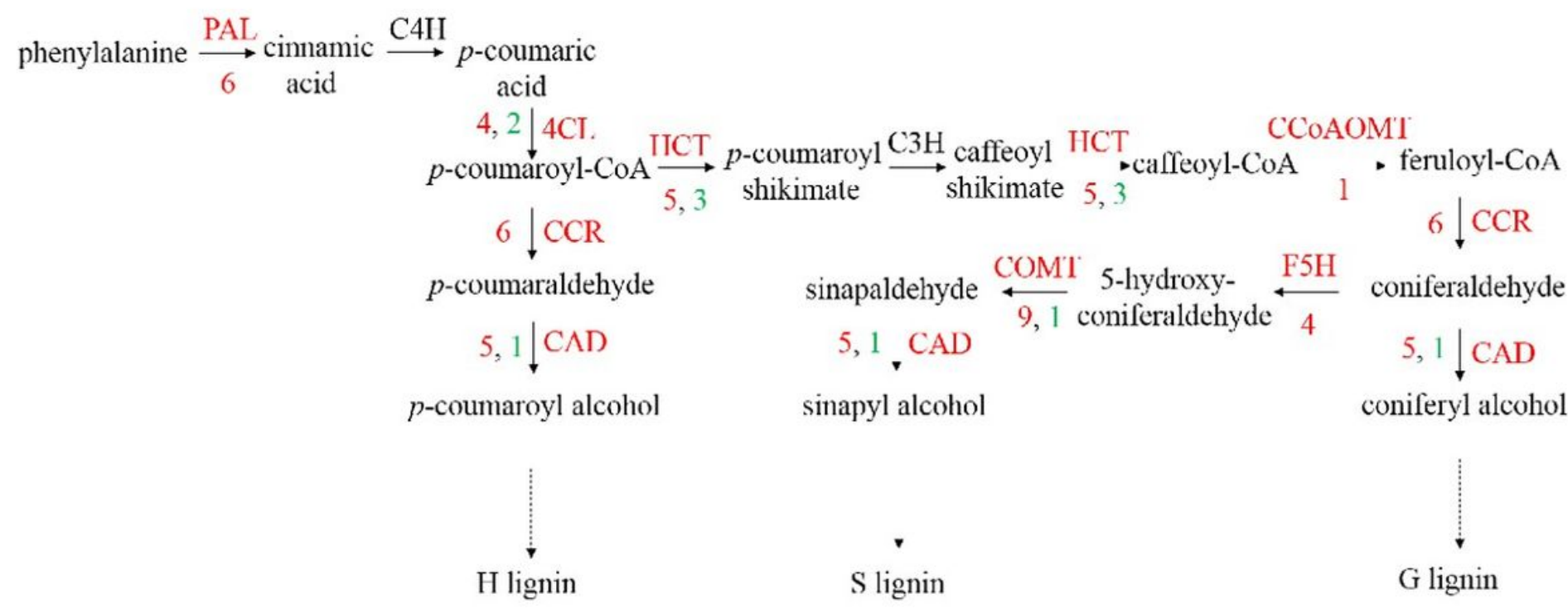

\section{Figure 12}

Lignin biosynthesis pathway [33]. Enzymes coloured in red or black indicate the key pointsinduced or uninduced by CEF-082. The red numbers represents the number of upregulated genes, and green numbers represent the number of downregulated genes. PAL, phenylalanine ammonia-lyase; $\mathrm{C} 4 \mathrm{H}$, cinnamate 4hydroxylase; $4 \mathrm{CL}$, 4-coumarate-CoA ligase; $\mathrm{C} 3 \mathrm{H}$, p-coumarate 3 hydroxylase; $\mathrm{HCT}$, hydroxycinnamoyl transferase; CCR, cinnamoyl CoA reductase; CAD, cinnamyl alcohol dehydrogenase; CCoAOMT, caffeoylCoA 0-methyltransferase; $\mathrm{F} 5 \mathrm{H}$, ferulate-5-hydroxylase.

\section{Supplementary Files}

This is a list of supplementary files associated with this preprint. Click to download.

- Additionalfiles6.docx

- Additionalfiles5.docx

- Additionalfiles4.docx

- Additionalfiles10.xIsx

- Additionalfiles9.xlsx

- Additionalfiles7.docx

- Additionalfiles2.docx

- Additionalfiles1.docx

- Additionalfiles3.docx

- Additionalfiles8.xIsx 